
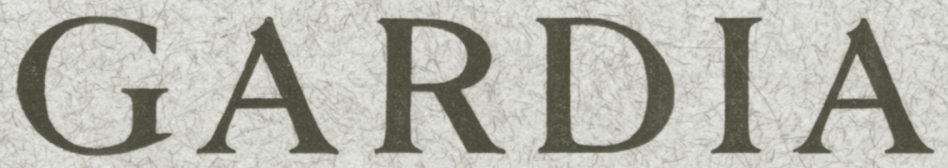

A Journal of Agricultural Science Published by the California Agricultural Experiment Station

\title{
THE IMPACT OF IRRIGATION ON FARM OUTPUT IN CALIFORNIA
}

\author{
VERNON W. RUTTAN
}


The problem of allocating water among production units, industries, or geographic units, and of planning water resource development, requires information of the relationship between water input, other inputs, and product outputs. The study reported herein was undertaken to determine the extent to which differences in the level of farm output in California counties can be accounted for by differences in irrigation or irrigation-associated inputs as compared with total complex of inputs used in agricultural production. A model is developed to identify the historical impaci of irrigation on California's farm output, and this is analyzed in order is project impact of future irrigation development on farm output. 


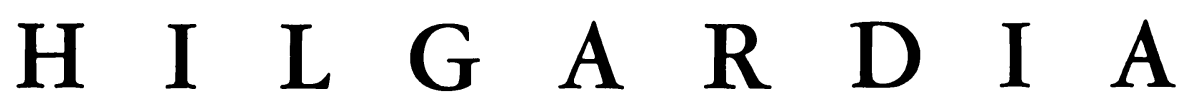

A Journal of Agricultural Science Published by

the California Agricultural Experiment Station

YoL. 31

JULY, 1961

No. 4

\section{THE IMPACT OF IRRIGATION ON FARM OUTPUT IN CALIFORNIA}

VERNON W. RUTTAN ${ }^{2}$

\section{INTRODUCTION}

SINCE THE mid-1920's, the share of national farm output produced in California has risen from 5.6 to almost 10 per cent. Irrigation has generally been regarded as an important factor in this growth. In spite of this, there has been little attempt to assess the importance of water and irrigated land in relation to other productive inputs in the growth of California farm output.

Some investigators tend to think in terms of "the quantity of irrigation water required for profitable crop production under the prevailing climate and physical conditions" (Fortier and Young, 1933; Blaney and Criddle, $1947),{ }^{3}$ and to consider growth of farm output, at both farm and area level, as primarily a function of the number of acres irrigated (Weeks, 1955). Other students tend to think in terms of yield response to alternative levels of water, irrigated land, and other inputs (Parks, 1956), and to consider growth of farm output as a function of the inputs of land, labor, capital, and current operating expenses (including water supplied by irrigation). According to this view, no single input is limitational.

Most discussions of the possibilities of farm output expansion recognize considerably more latitude for input substitution than is implied by the use of the "irrigation requirement" concept (Stockton and Doneen, 1957; Hedges and Bailey, 1952). For example, in 1952 the California State Committee on Survey of Agricultural Productive Capacity reported that “... California's agricultural plant is highly flexible. It can be quickly redirected toward greater output..." and "The projected high levels of California's agricultural production are dependent upon ample supplies of machines, irrigation equipment, feeds, fertilizers, pesticides, and related materials. Adequate labor is of prime importance ..." (Hedges and Bailey, 1952).

Part of this apparent disagreement has stemmed from the limited analyti-

${ }^{1}$ Submitted for publication, March, 1960.

2 Associate Agricultural Economist, Department of Agricultural Economics, University of California, Berkeley (on leave from the Department of Agricultural Economies, Purdue University).

"See "Literature Cited" for citations referred to in the text by author and date. 
cal framework within which some students have cast their analysis. Beringer (1961) has recently shown that the basis for disagreement can be narrowed considerably when the different models of production employed by agronomists and economists are viewed against the different research objectives in the two fields. It also seems clear that at least part of the apparent disagreement stems from the fact that information concerning the relationships between inputs and outputs which may be very useful in answering private management or policy problems at the farm level may provide inadequate guides to the solution of public policy problems at the state or national level.

Information on the relationships between water input, other inputs, and product output is useful at several major levels:

1. Decisions regarding the allocation of water or irrigated land among different uses and over time within an individual production unit such as a farm or an industrial firm.

2. The problem of allocating water among individual production units, industries, or geographic areas, and of planning for additional water resource developments.

Problem 1 has both short-run and long-run dimensions. The short-run problem of factor utilization in the case of a farm or industrial firm is primarily a problem of technical economics; technical response data are combined with input and product price data to arrive at an allocation decision. The longer-run adjustment planning problem, where the objective of the firm is to change the combination of inputs (including water), the product mix, production practices, and technology, is also primarily a problem in technical economics, though a more complex one. Two primary reasons for this increase in complexity are that production response data have usually been obtained by holding constant many of the factors which the planner (manager) wishes to alter, and that the additional costs and returns no longer have approximately the same time sequence as they have in the shortrun allocation problem.

Problem 2 also has two dimensions. In allocating existing water supplies among individual firms, industries, or areas, social and political-economic relationships play a more important role relative to technical input-output and production response relationships than they do in allocation decisions at the intrafirm level. There are two reasons for this: technical and equity considerations frequently conflict with each other until either technology or institutional arrangements can be modified, and secondly, interactions between economic units are so complex that they can be understood only by resorting to a rather high degree of abstraction. Thus, it becomes necessary to deal with aggregate production functions, highly simplified activities, or aggregate cost-benefit budgeting procedures which reflect the interaction of both technical and institutional factors rather than primary input-output or production response relationships. At this level the principal contribution of economic analysis is to clarify the effects on resource utilization and on income distribution of conflicts between equity and technical considerations, and of policies designed to deal with such conflicts.

In planning for additional water resource development, failure of the incidence and time sequence of costs and returns to coincide results in social 
and political-economic considerations becoming even more important relative to technical-economic considerations. Here, the principal contribution of economic analysis is to clarify the effects of alternative resource development policies and programs on resource utilization and income distribution over time.

\section{OBJECTIVES AND PROCEDURES}

The purpose of the present study is to provide information relevant to water allocation and resource development decisions at the second level discussed above. Specifically, the study will attempt:

1. To determine the extent to which differences in the level of farm output among California counties can be accounted for by differences in irrigation or irrigation-associated inputs as compared to the total complex of inputs used in agricultural production.

2. To evaluate the usefulness of the model used to identify the historical impact of irrigation on farm output in California as a tool for projecting the impact of future irrigation development on farm output.

The procedure for the first objective will involve fitting a Cobb-Douglas type function to aggregate factor input and output data available from the Census of Agriculture and the Census of Irrigation for California counties for 1940, 1950, and 1955, and a comparison of the amount of variation in total farm output explained by the total complex of inputs with the amount of variation explained by a subset of irrigation or irrigation-associated inputs.

The procedure for the second objective will be to analyze the production relationships identified under the first objective in terms of their potential usefulness in projecting the impact of additional irrigation development on farm output in California. This will involve an analysis of the stability and/or shifts in the coefficients of the production relationships in relation to changes in technology and in the prices of input factors and products.

If successful, this approach should provide a useful supplement to the aggregate budgeting techniques currently used in evaluating the costs and benefits of water resource development.

A number of questions are raised regarding the procedure outlined above:

1. The Cobb-Douglas function $\left(X_{0}=A \prod_{i=1}^{n} X_{i}^{\alpha_{i}}\right)$ employed as a model of production in this study has serious limitations (Haver, 1956). (a) The function will exhibit increasing, constant or decreasing returns to scale but only singly and not in combination. (b) Complementarity is forced as the iso-product curves become asymptotic to the axes. (c) If the level of any input drops to zero the entire function collapses because output is a function of the product of the inputs. (d) Marginal productivities estimated at points below or above the geometric mean may be subject to serious bias.

On the other hand, the Cobb-Douglas function does have a number of important advantages as listed by Tintner (1944). It gives immediate elasticities of the product with respect to the factors of production, it permits decreasing marginal returns to come into evidence without using too many degrees of freedom, it permits the use of standard statistical tests more readily than other nonlinear functions, and it is useful for industrial appli- 
cation at the macroeconomic level, as shown by Douglas and his associates, and at the microeconomic level, as shown by a number of agricultural economists.

2. A second criticism of the proposed procedure is that the observed inputs and outputs may reflect the simultaneous interaction of product demand, factor supply, and the aggregate production function rather than the effect of the production function alone. If this criticism is valid, the least-squares method applied to a single equation -in this case the production functionof the complete system of equations which generated the observed inputs and outputs will result in bias in the estimated parameters of the statistical production functions. This bias can be particularly bothersome when the objective is to evaluate the impact of changes in technology or scale on the parameters of the production function or to measure the effect of arbitrary changes in input combinations on output (Marschak and Andrews, 1944; Bronfenbrenner, 1944; Hoch, 1957). The fact that inputs tend to be fixed for the production period in agriculture may indicate that the problem discussed above is less important in the agricultural sector than in other sectors of the economy.

3. One may also object to using counties rather than individual farms as the basic unit of analysis. The farm, rather than the county, is usually the primary behavior unit. Summing of inputs and outputs across farms to form county aggregates lumps together units with different enterprise combinations, levels of intensity, and levels of efficiency into a single unit which may not be meaningful for economic analysis. These questions have been discussed extensively in the literature, particularly with respect to use of the CobbDouglas formulation (Bronfenbrenner, 1944; Durand, 1937; Hoch, 1957).

These criticisms are most valid if one is attempting to use aggregate production functions to make generalizations concerning firm behavior. It can be argued that these criticisms are less valid when the purpose of the analysis is to make inferences concerning the aggregate effect of changes in resource use and that given the present inadequacy of composition laws aggregate behavior is best predicted on the basis of relationships estimated from aggregate data (Klein, 1956; Griliches and Grenfeld, 1960).

Even if one agrees with this argument, the question still arises as to whether it might not be possible to choose a more suitable unit for analysis than the county. If one were free to redraw the map of California and reassemble farm output and input data to reflect new geographic units, a system superior to the present county outlines could almost certainly be found. The need for relying on census data seems to preclude use of other units in this study.

4. One may also object that the method proposed assumes that there is a single discoverable production function for California agriculture as a whole or even for its major subregions. Does not the diversity of climatic, physiographic, and institutional characteristics of California agriculture suggest that separate production functions be constructed for smaller areas defined on the basis of these characteristics?

There is a strong basis for this objection. It is equally valid whether individual farms or some aggregate category such as irrigation districts, town- 
ships, or counties are used as the basic unit of analysis. There are two reasons for proceeding as outlined above in spite of these objections. (a) The number of possible alternative bases for classification make it difficult to define on an $a$ priori basis what type of segmentation would be most appropriate. (b) The analysis will combine a rather large number of independent variables with a limited number of observations. Segmentation of counties into more than two groups would drastically reduce the degrees of freedom in the regression analysis.

5. It is also anticipated that the analysis will be complicated by fairly high intercorrelation between some of the "independent" variables. A certain amount of bias will be introduced into the estimates of the parameters as a result of incomplete specification of the independent variables. There is no entirely satisfactory way of dealing with these problems.

It is frequently possible, however, to evaluate the effect of high intercorrelation. Fox and Cooney (1954) have investigated this problem in considerable detail. In some cases it is possible to deal with the problem by treating highly intercorrelated independent variables as a "bundle" of inputs which should be varied in an approximately constant ratio to each other.

In the case of specification bias, it is frequently possible to arrive at reasonable conclusions regarding the direction and, in some cases, even the relative magnitude of the bias in the estimates of the parameters (Griliches, 1957).

6. A sixth objection relates to the adequacy and continuity of census data. Data on machinery investment has, for example, not been covered in the Census of Agriculture since 1945. Data on livestock investment was discontinued after 1950. Sufficient data on livestock and machinery inventories are available to construct, with the aid of 1945 and 1950 data on both inventory and investment, suitable indexes of livestock and machinery investment for use in 1950 and 1955. A more complete discussion of the data and data sources is presented in Appendix A.

It is difficult to evaluate on an a priori basis the degree to which the limitations discussed above will affect the results of the analysis. Only when the analysis is completed will it be possible to arrive at a final judgment as to the usefulness of the approach.

The potential weaknesses of the procedure imply that the results should be used with considerable caution. Confidence in the results will be strengthened if the implications drawn from analysis of aggregate data indicate the same type of behavior as analysis conducted at a lower level of aggregation. On the other hand, lack of apparent consistency between analyses at successive levels of aggregation is not prima facie evidence of error at either level but may indicate a need for further examination of how elementary relationships interact to produce aggregate behavior. 


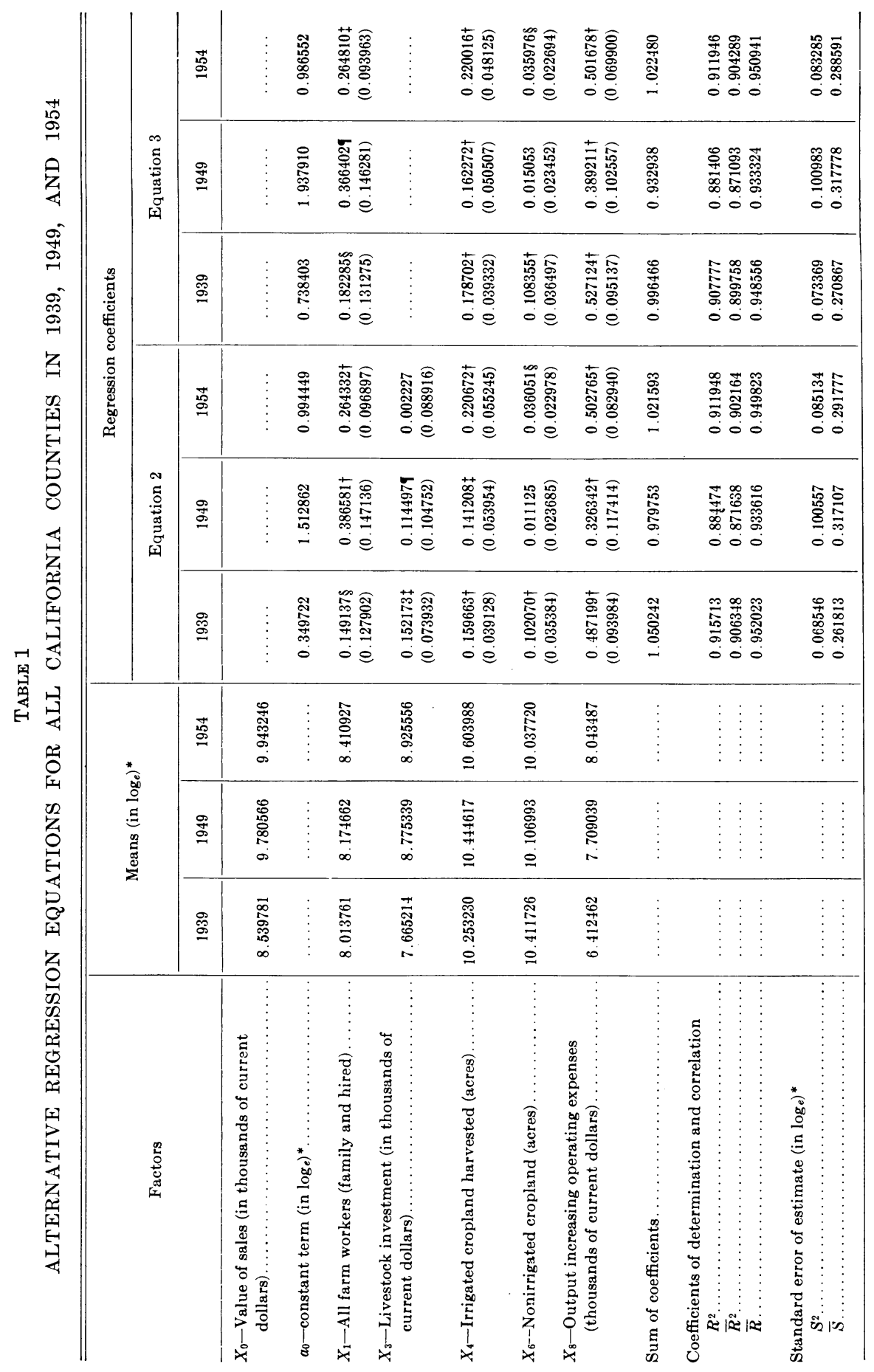




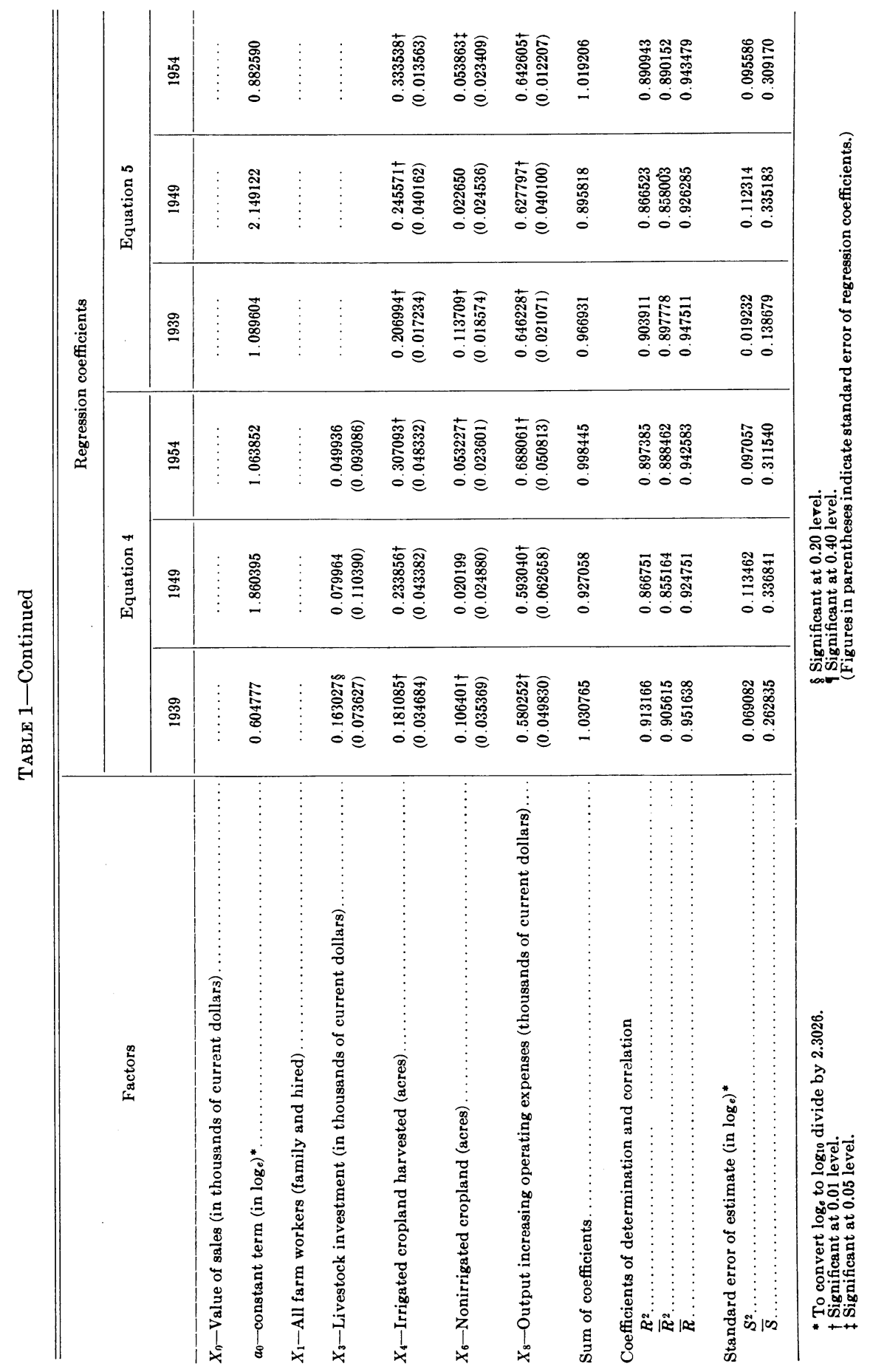




\section{STATISTICAL ANALYSIS OF FACTORS AFFECTING FARM OUTPUT IN CALIFORNIA}

The statistical investigation was designed to test the hypothesis that variations in farm output, measured in terms of the sales of farm products $\left(\mathrm{X}_{0}\right)$, among California counties are significantly related to variations in the 11 variables listed below. A complete listing of the data sources and limitations is presented in Appendix A.

\section{Factors}

Specific variables

Labor ................ $\mathrm{X}_{1}$-total family and hired workers employed Nonland capital inputs..... $\mathrm{X}_{2}-$ machinery and equipment investment

$\mathrm{X}_{3}$-livestock investment

Irrigated land $\ldots \ldots \ldots \ldots \mathrm{X}_{4}$-irrigated cropland harvested

$\mathrm{X}_{5}$-irrigated pasture

Nonirrigated land . . ....... $\mathrm{X}_{6}-$ nonirrigated cropland harvested

$\mathrm{X}_{\tau}$-nonirrigated pasture

Current inputs $\ldots \ldots \ldots \ldots X_{8}-$ output increasing operating expenses (purchased feed, fertilizer, insecticides, etc.)

$\mathrm{X}_{9}$-capital equipment operating expenses (gasoline, distillate, repairs, etc.)

$\mathrm{X}_{10}$-irrigation water applied

Population pressure ....... $\mathrm{X}_{11}$-total county population

Of the 11 variables included in the analysis, only 3 yielded coefficients that were significantly different from zero (on the basis of the t test) in all 3 years at either the $0.20,0.10,0.05$, or 0.01 levels.

The original hypothesis was then reformulated in terms of 5 independent variables-farm employment $\left(X_{1}\right)$, livestock investment $\left(X_{3}\right)$, irrigated cropland $\left(\mathrm{X}_{4}\right)$, nonirrigated cropland $\left(\mathrm{X}_{6}\right)$, and output increasing operating expense $\left(X_{8}\right)$.

In reformulating the hypothesis several elements were considered in addition to the significance tests:

1. Equipment operating expenses $\left(X_{9}\right)$ was dropped from the list of independent variables in spite of the fact that the coefficient for $X_{9}$ was significant at the 0.01 level. The high intercorrelations between $X_{9}$ and several other independent variables, particularly farm employment $\left(X_{1}\right)$ and output increasing operating expenses $\left(\mathrm{X}_{8}\right)$ seemed to imply that machinery operating expenses are associated with these other two input categories in a complementary manner rather than as a substitute.

2 . The farm employment variable $\left(X_{1}\right)$ was retained in spite of a negative regression coefficient and high intercorrelations with several other independent variables, particularly output increasing operating expenses $\left(\mathrm{X}_{8}\right)$, on the hypothesis that labor inputs should, on economic grounds, be associated with the other four independent variables as substitutes rather than as complements.

3. Irrigated cropland $\left(\mathrm{X}_{4}\right)$ was also retained in spite of the fact that the 
coefficient was not statistically significant at the indicated levels. After equipment operating expenses $\left(\mathrm{X}_{9}\right)$ was dropped as an independent variable it seemed reasonable to expect that the coefficients for labor $\left(X_{1}\right)$ and for irrigated cropland $\left(\mathrm{X}_{4}\right)$ might no longer be "repressed" due to the effect of high intercorrelation.

4. The possibility of dropping livestock investment $\left(X_{3}\right)$ as an independent variable and retaining irrigated pasture $\left(X_{5}\right)$ and nonirrigated pasture $\left(X_{7}\right)$ was also considered on the grounds that livestock investment represents

TABLE 2

COEFFICIENTS OF SIMPLE CORRELATION FOR ALL CALIFORNIA COUNTIES, 1939, 1949, ANI) 1954

\begin{tabular}{|c|c|c|c|c|c|c|}
\hline \multirow{2}{*}{ Factors } & \multicolumn{6}{|c|}{ Coefficients of correlation } \\
\hline & $r_{0}$ & $r_{1}$ & $r_{3}$ & $r_{4}$ & $r_{6}$ & $r_{3}$ \\
\hline $\begin{array}{l}1954 \text { : } \\
\quad \text { Value of sales } \ldots \ldots \ldots \ldots \ldots \ldots \ldots \ldots \ldots r_{0} \\
\text { All farm workers } \ldots \ldots \ldots \ldots \ldots \ldots \ldots r_{1} \\
\text { Value of livestock } \ldots \ldots \ldots \ldots \ldots \ldots r_{3} \\
\text { Irrigated cropland harvested } \ldots \ldots \ldots \ldots r_{4} \\
\text { Nonirrigated cropland harvested } \ldots \ldots r_{6} \\
\text { Output increasing operating expense } \ldots r_{8}\end{array}$ & $\begin{array}{l}1.000000 \\
\ldots \ldots \\
\ldots \ldots \ldots \\
\cdots \cdots \cdots \\
\cdots \cdots \\
\cdots \cdots\end{array}$ & $\begin{array}{l}0.945388 \\
1.000000 \\
\ldots \ldots \ldots \\
\ldots \ldots \ldots \\
\ldots \ldots \ldots \\
\ldots \ldots \ldots\end{array}$ & $\begin{array}{l}0.766274 \\
0.717276 \\
1.000000 \\
\ldots \ldots \ldots \\
\ldots \ldots \ldots \\
\ldots \ldots \ldots\end{array}$ & $\begin{array}{l}0.778570 \\
0.722391 \\
0.639203 \\
1.000000 \\
\ldots \ldots \ldots \\
\ldots \ldots \ldots\end{array}$ & $\begin{array}{c}0.347155 \\
0.361114 \\
0.233589 \\
0.239429 \\
1.000000 \\
\ldots \ldots \ldots\end{array}$ & $\begin{array}{l}0.931531 \\
0.903250 \\
0.754462 \\
0.572774 \\
0.271227 \\
1.000000\end{array}$ \\
\hline $\begin{array}{l}\text { 1949: } \\
\quad \text { Value of sales } \ldots \ldots \ldots \ldots \ldots \ldots \ldots \ldots r_{0} \\
\text { All farm workers } \ldots \ldots \ldots \ldots \ldots \ldots \ldots r_{1} \\
\text { Value of livestock } \ldots \ldots \ldots \ldots \ldots \ldots r_{3} \\
\text { Irrigated cropland harvested } \ldots \ldots \ldots \ldots r_{4} \\
\text { Nonirrigated cropland harvested } \ldots \ldots r_{6} \\
\text { Output increasing operating expense } . r_{8}\end{array}$ & $\begin{array}{l}1.000000 \\
\ldots \ldots \ldots \\
\ldots \ldots \ldots \\
\ldots \ldots \ldots \\
\ldots \ldots \ldots \\
\ldots \ldots \ldots\end{array}$ & $\begin{array}{l}0.955737 \\
1.000000 \\
\ldots \ldots \ldots \\
\ldots \ldots \ldots \\
\ldots \ldots \ldots \\
\ldots \ldots \ldots\end{array}$ & $\begin{array}{l}0.834544 \\
0.816391 \\
1.060000 \\
\ldots \ldots \ldots \\
\ldots \ldots \ldots \\
\ldots \ldots \ldots\end{array}$ & $\begin{array}{l}0.715343 \\
0.665376 \\
0.550973 \\
1.000000 \\
\ldots \ldots \ldots \\
\ldots \ldots \ldots\end{array}$ & $\begin{array}{l}0.337683 \\
0.339110 \\
0.338960 \\
0.211294 \\
1.000000\end{array}$ & $\begin{array}{l}0.887471 \\
0.914188 \\
0.827369 \\
0.410736 \\
0.304320 \\
1.000000\end{array}$ \\
\hline $\begin{array}{l}\text { 1939: } \\
\quad \text { Value of sales } \ldots \ldots \ldots \ldots \ldots \ldots \ldots \ldots r_{0} \\
\text { All farm workers } \ldots \ldots \ldots \ldots \ldots \ldots \ldots r_{1} \\
\text { Value of livestock } \ldots \ldots \ldots \ldots \ldots r_{3} \\
\text { Irrigated cropland harvested } \ldots \ldots \ldots \ldots r_{4} \\
\text { Nonirrigated cropland harvested } \ldots \ldots r_{6} \\
\text { Output increasing operating expense } \ldots r_{8}\end{array}$ & $\begin{array}{l}1.000000 \\
\ldots \ldots \ldots \\
\ldots \ldots \ldots \\
\ldots \ldots \ldots \\
\ldots \ldots \ldots \\
\ldots \ldots \ldots\end{array}$ & $\begin{array}{l}0.942008 \\
1.000000 \\
\ldots \ldots \ldots \\
\ldots \ldots \ldots \\
\ldots \ldots \ldots \\
\ldots \ldots \ldots\end{array}$ & $\begin{array}{l}0.780224 \\
0.754327 \\
1.000000 \\
\ldots \ldots \ldots \\
\ldots \ldots \ldots \\
\ldots \ldots \ldots\end{array}$ & $\begin{array}{l}0.637161 \\
0.561165 \\
0.463038 \\
1.000000 \\
\ldots \ldots \ldots \\
\ldots \ldots \ldots\end{array}$ & $\begin{array}{l}0.697139 \\
0.641994 \\
0.529405 \\
0.344335 \\
1.000000 \\
\ldots \ldots \ldots\end{array}$ & $\begin{array}{l}0.920681 \\
0.933887 \\
0.732438 \\
0.383399 \\
0.637290 \\
1.000000\end{array}$ \\
\hline
\end{tabular}

an input that interacts with the two pasture input variables ( $\mathrm{X}_{5}$ and $\mathrm{X}_{\text {- }}$ ) in a complementary manner. It was finally decided to retain livestock investment as an independent variable and drop the two pasture input variables. It seemed likely that livestock investment might represent a more accurate "index" of pasture inputs than the two pasture input variables themselves, as livestock investment reflects to a certain extent the carrying capacity of the pasture.

The results of the statistical analysis obtained after this reformulation are presented as equation 2 in table 1, and are shown in table 2 . The other equations presented in table 1 represent strictly empirical attempts to investigate the effects of dropping one or more of the variables included in equation 2. The modifications presented in equations 3 and 5 seem to express the relationships between inputs and output at the state level more adequately than the other sets of equations presented in table 1 . 
The question still arises as to whether, given the wide differences in climatic and physiographic characteristics among California counties, greater precision could not be introduced into the analysis by segmenting the state into at least two groups of counties selected in such a manner as to increase the internal homogeneity of each group.

An attempt has been made to achieve greater homogeneity by grouping counties into two groups on the basis of the number of acres of irrigated

Shaded areas are major irrigation counties; unshaded are limited irrigation counties.

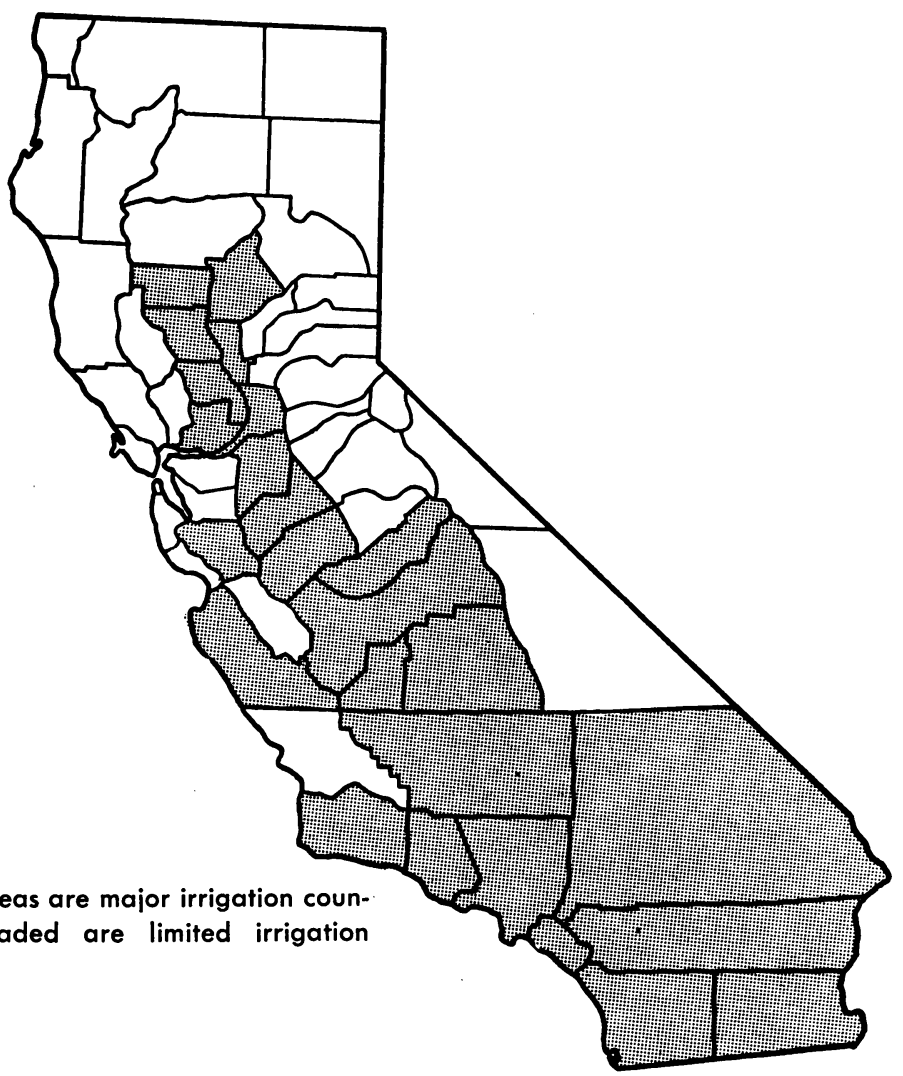

Fig. 1

cropland harvested. There were 25 counties in southern California and the San Joaquin and Sacramento valleys in which more than 50,000 acres of irrigated cropland were harvested and 26 other counties in which fewer than 50,000 acres of irrigated cropland were harvested in 1954 . The 25 counties with more than 50,000 acres of irrigated cropland harvested in 1954 are, by and large, the counties into which additional water will be transported by projects currently underway or planned for future development by the $\mathrm{Bu}$ reau of Reclamation and the State of California (California Water Resources Board, 1955). The counties with less than 50,000 acres of irrigated cropland harvested in 1954 are considerably more heterogeneous in character. They 
include counties with the highest annual precipitation in the state as well as counties ranking among the lowest in precipitation. The most important similarity among them is the fact that they include relatively few acres of irrigated cropland at present." According to estimates of the California Department of Water Resources, this condition is likely to continue (California Water Resources Board, 1955).

Major Irrigation Counties
2. Butte
3. Colusa
5. Fresno
6. Glenn
7. Imperial
8. Kern
9. Kings
12. Los Angeles
13. Marlera
16. Merced
18. Monterey
21. Orange
23. Riverside
24. Sacramento
26. San Bernardino
27. San Diego
28. San Joaquin
31. Santa Barbara
32. Santa Clara
37. Solano
39. Stanislaus
40. Sutter
43. Tulare
44. Ventura
45. Yolo

Limited Irrigation Counties
1. Alameda
4. Contra Costa
10. Lake
11. Lassen
14. Marin
15. Mendocino
17. Modoc
19. Napa
20. Nevada
22. Plumas
25. San Benito
29. San Luis Obispo
30. San Mateo
33. Santa Cruz
34. Shasta
35. Sierra
36. Siskiyou
38. Sonoma
41. Tehama
42. Trinity
46. Yuba
47. Mono-Inyo
48. Placer-El Dorado
49. Alpine-Amador-Calaveras
50. Tuolumne-Mariposa
51. Del Norte-Humboldt

For the 25 major irrigation counties, it seems clear from the data presented in tables 3 and 4 that equation 6 provides the most adequate description of the relationship between inputs and outputs during the 3 years included in the study. If the year 1939 only were being considered, equation 3 might, under some criteria, be judged the most adequate. Even in 1939 the standard errors of the individual regression coefficients are considerably lower in equation 6 than in equation 3. In spite of the relatively high regression coefficients for farm employment $\left(X_{1}\right)$, inclusion of the variable adds practically nothing to the predictive accuracy of the equation. This stems from the high intercorrelation between labor inputs and output-increasing operating expenses. Apparently labor, as used on farms in the major irrigation

\footnotetext{
${ }^{4}$ This statement should be qualified in one respect. Siskiyou County, with 55,275 acres of irrigated cropland in 1955, is included in this second group of counties because of similarities to other northern California counties. There are 58 counties in California; San Francisco County was omitted because of its limited amount of agriculture. Placer and El Dorado, Alpine, Amador, and Calaveras, Tuolumne and Mariposa, Del Norte and Humboldt, and Mono and Inyo counties were grouped because of the low value of farm output produced in each. This reduced the number of units dealt with in the analysis from 58 to 51 .
} 


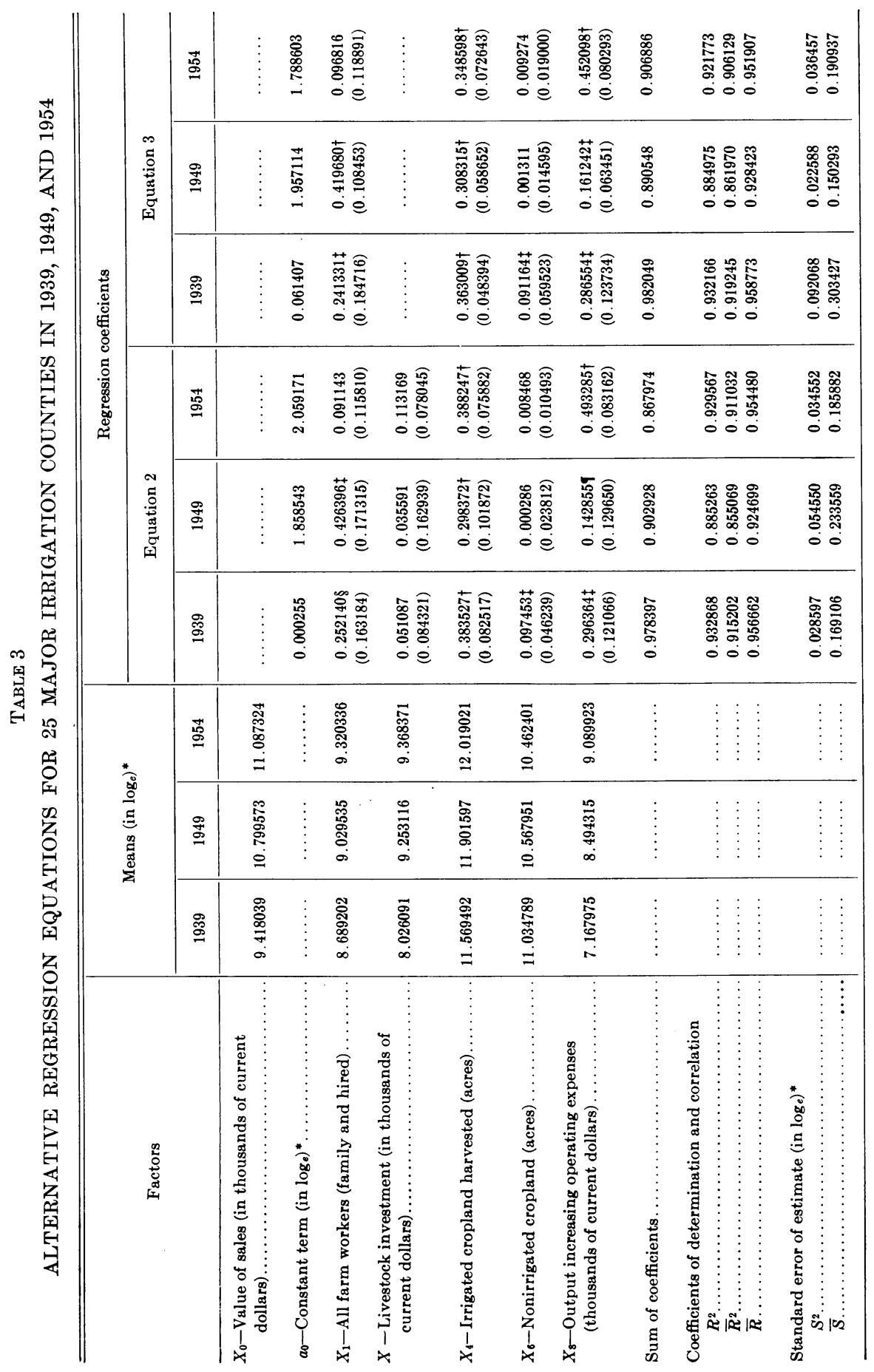




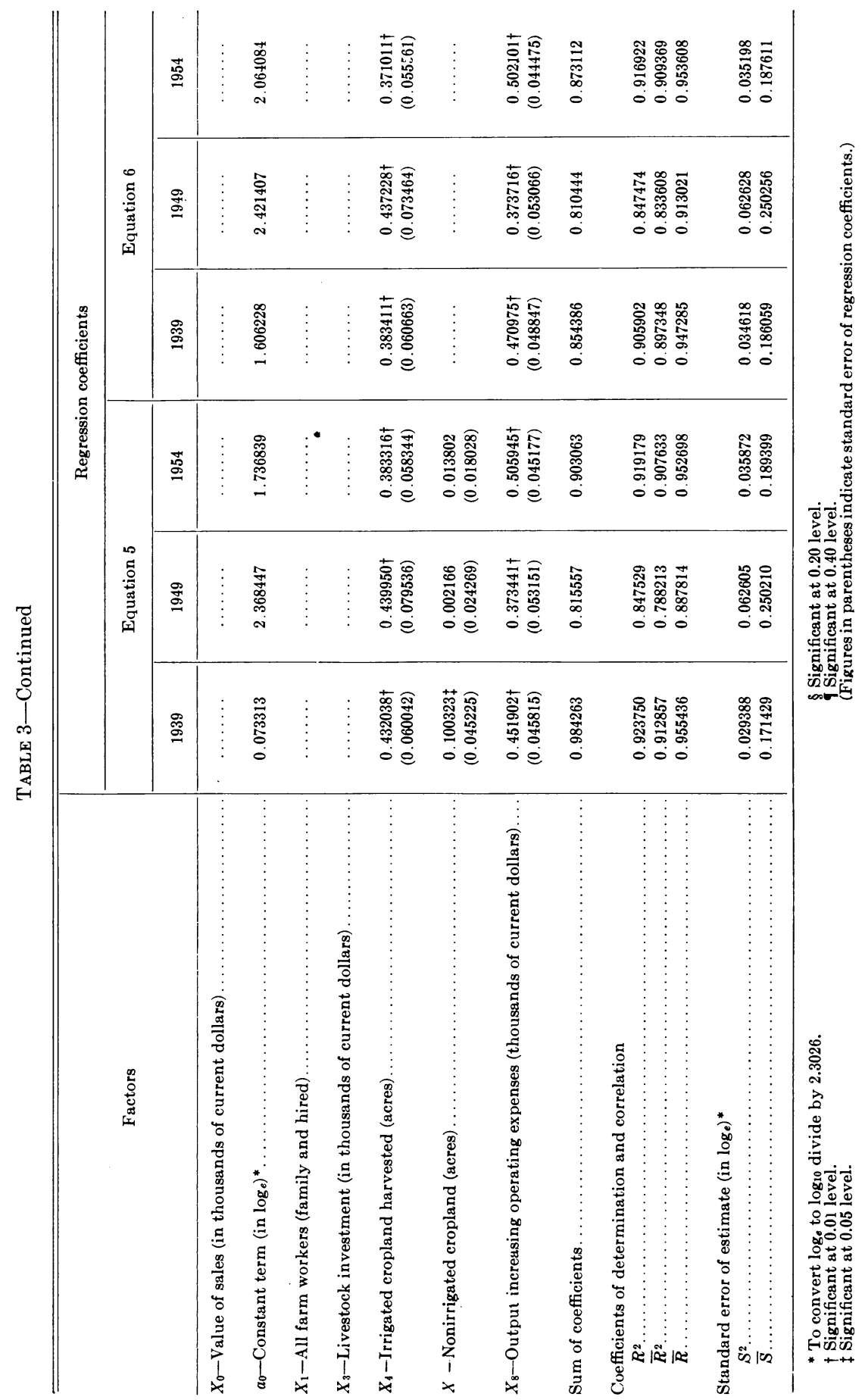


counties of California, can be regarded as a substitute for other inputs only to a very limited extent. It is not clear whether this is a reflection primarily of technical-economic relationships or a combination of technical and socioeconomic relationships.

One should also draw attention to the relatively low regression coefficient for output-increasing operating expenses and the relatively high coefficient for labor in 1949. This reflects a limitation in the data on current operating expenses for 1940. The 1949 Census does not provide data on fertilizer and

TABLE 4

COEFFICIENTS OF SIMPLE CORRELATION FOR MAJOR IRRIGATION COUNTIES, 1939, 1949, AND 1954

\begin{tabular}{|c|c|c|c|c|c|c|}
\hline \multirow{2}{*}{ Factors } & \multicolumn{6}{|c|}{ Coefficients of correlation } \\
\hline & $r_{0}$ & $r_{1}$ & $r_{3}$ & $r_{4}$ & $r_{6}$ & $r_{8}$ \\
\hline $\begin{array}{l}\text { 1954: } \\
\quad \text { Value of sales } \ldots \ldots \ldots \ldots \ldots \ldots \ldots \ldots r_{0} \\
\text { All farm workers } \ldots \ldots \ldots \ldots \ldots \ldots r_{1} \\
\text { Livestock investment. } \ldots \ldots \ldots \ldots \ldots r_{3} \\
\text { Irrigated cropland harvested } \ldots \ldots \ldots r_{4} \\
\text { Nonirrigated cropland harvested } \ldots \ldots r_{6} \\
\text { Output increasing operating expense } . r_{8}\end{array}$ & $\begin{array}{c}1.000000 \\
\ldots \ldots \ldots \\
\ldots \ldots \ldots \\
\ldots \ldots \ldots \\
\ldots \ldots \ldots \\
\ldots \ldots \ldots\end{array}$ & $\begin{array}{l}\mathbf{0 . 8 6 1 6 9 5} \\
1.000000 \\
\ldots \ldots \ldots \\
\ldots \ldots \ldots \\
\ldots \ldots \ldots \\
\ldots \ldots \ldots\end{array}$ & $\begin{array}{l}\mathbf{0 . 5 7 9 1 5 1} \\
\mathbf{0 . 5 6 5 1 9 1} \\
1.000000 \\
\ldots \ldots \ldots \\
\ldots \ldots \ldots \\
\ldots \ldots \ldots\end{array}$ & $\begin{array}{l}0.659971 \\
0.551745 \\
0.517394 \\
1.000000 \\
\ldots \ldots \ldots \\
\ldots \ldots \ldots\end{array}$ & $\begin{array}{r}-0.238642 \\
-0.111074 \\
-0.240032 \\
-0.318677 \\
1.060000 \\
\ldots \ldots \ldots\end{array}$ & $\begin{array}{r}0.865176 \\
0.811301 \\
0.579336 \\
0.312227 \\
-0.199563 \\
1.000000\end{array}$ \\
\hline $\begin{array}{l}\text { 1949: } \\
\quad \text { Value of sales } \ldots \ldots \ldots \ldots \ldots \ldots \ldots \ldots r_{0} \\
\text { All farm workers } \ldots \ldots \ldots \ldots \ldots \ldots \ldots r_{1} \\
\text { Livestock investment } \ldots \ldots \ldots \ldots \ldots r_{3} \\
\text { Irrigated cropland harvested } \ldots \ldots \ldots \ldots r_{4} \\
\text { Nonirrigated cropland harvested } \ldots \ldots r_{6} \\
\text { Output increasing operating expense } \ldots r_{8}\end{array}$ & $\begin{array}{l}1.000000 \\
\ldots \ldots \ldots \\
\ldots \ldots \ldots \\
\ldots \ldots \ldots \\
\ldots \ldots \ldots \\
\ldots \ldots \ldots\end{array}$ & $\begin{array}{l}0.899131 \\
1.000000 \\
\ldots \ldots \ldots \\
\ldots \ldots \ldots \\
\ldots \ldots \ldots \\
\ldots \ldots \ldots\end{array}$ & $\begin{array}{l}0.723428 \\
0.721288 \\
1.000000 \\
\ldots \ldots \ldots \\
\ldots \ldots \ldots \\
\ldots \ldots \ldots\end{array}$ & $\begin{array}{c}0.709694 \\
0.563625 \\
0.439682 \\
1.000000 \\
\ldots \ldots \ldots \\
\ldots \ldots \ldots\end{array}$ & $\begin{array}{r}-0.234881 \\
-0.172888 \\
0.019230 \\
-0.384782 \\
1.000000 \\
\ldots \ldots \ldots\end{array}$ & $\begin{array}{r}0.775829 \\
0.852724 \\
0.815867 \\
0.306842 \\
-0.067180 \\
1.000000\end{array}$ \\
\hline $\begin{array}{l}\text { 1939: } \\
\quad \text { Value of sales } \ldots \ldots \ldots \ldots \ldots \ldots \ldots \ldots r_{0} \\
\text { All farm workers } \ldots \ldots \ldots \ldots \ldots \ldots \ldots r_{1} \\
\text { Livestock investment } \ldots \ldots \ldots \ldots \ldots r_{3} \\
\text { Irrigated cropland harvested } \ldots \ldots \ldots \ldots r_{4} \\
\text { Nonirrigated cropland harvested } \ldots \ldots r_{6} \\
\text { Output increasing operating expense } \ldots r_{8}\end{array}$ & $\begin{array}{l}1.000000 \\
\ldots \ldots \ldots \\
\ldots \ldots \ldots \\
\ldots \ldots \ldots \\
\ldots \ldots \ldots \\
\ldots \ldots \ldots\end{array}$ & $\begin{array}{l}0.921287 \\
1.000000 \\
\ldots \ldots \ldots \\
\ldots \ldots \ldots \\
\ldots \ldots \ldots \\
\ldots \ldots \ldots\end{array}$ & $\begin{array}{l}\mathbf{0 . 7 1 4 2 6 8} \\
\mathbf{0 . 7 1 0 7 6 3} \\
1.000000 \\
\ldots \ldots \ldots \\
\ldots \ldots \ldots \\
\ldots \ldots \ldots\end{array}$ & $\begin{array}{l}0.712897 \\
0.575257 \\
0.607067 \\
1.000000 \\
\ldots \ldots \ldots \\
\ldots \ldots \ldots\end{array}$ & $\begin{array}{r}0.007389 \\
-0.011182 \\
0.030361 \\
-0.321237 \\
1.000000 \\
\ldots \ldots \ldots\end{array}$ & $\begin{array}{l}0.857338 \\
0.923133 \\
0.640136 \\
0.386925 \\
0.039670 \\
1.000000\end{array}$ \\
\hline
\end{tabular}

lime purchased; thus, output increasing current operating expenses $\left(\mathrm{X}_{8}\right)$ in 1949 reflects feed purchased only. The fact that the coefficient for $\mathrm{X}_{8}$ drops sharply when fertilizer and lime are omitted and the coefficient for labor $\left(\mathrm{X}_{1}\right)$ (with which $\mathrm{X}_{8}$ is closely correlated in the other two years) rises sharply increases confidence in the validity of the coefficients for $\mathrm{X}_{8}$ in both 1939 and 1954.

From the data presented in table 5, is appears that substitution among inputs in the major irrigation counties of California is largely limited to substitution between two groups of inputs-irrigated cropland and outputincreasing operating expenses. Confidence in this conclusion is fortified by the stability of the regression coefficients for these two variables over time, by the small standard errors of the two regression coefficients and by the relatively small standard error of estimate for the regression equation. 
For the 26 limited irrigation counties, it seems clear from the data presented in tables 5 and 6 that equation 5 provides the most adequate description of the relationship between inputs and outputs over the three years included in the study. As in the case of the major irrigation counties, the relatively high coefficient for farm employment in equation 3 adds very little to the predictive accuracy of the equation. Furthermore the standard errors of the regression coefficients are lower in equation 5 than in equation 3.

It was expected that the relative importance of the livestock industry in the limited irrigation counties would result in a significant coefficient for livestock investment $\left(\mathrm{X}_{3}\right)$. This expectation was fulfilled in 1939 only.

Two sharp differences stand out between the major irrigation counties and the limited irrigation counties:

1. The coefficient for irrigated cropland is considerably lower in the limited irrigation counties than in the major irrigation counties. A 10 per cent increase in irrigated cropland would result in an increase in output of approximately 4 per cent on the average in the major irrigation counties. In the limited irrigation counties, a 10 per cent increase in irrigated cropland would result in an increase in output of only about 2 per cent on the average.

2. In the limited irrigation counties, the coefficient for nonirrigated cropland $\left(\mathrm{X}_{6}\right)$ is consistently significantly greater than zero. The possibilities for substitution among inputs are, therefore, somewhat broader in the limited irrigation counties than in the major irrigation counties. The coefficient for $\mathrm{X}_{6}$ is considerably less stable than for either irrigated cropland $\left(\mathrm{X}_{4}\right)$ or current operating expenses $\left(\mathrm{X}_{8}\right)$. This seems reasonable in view of the fact that variations in the level of precipitation have a much more direct impact on output on nonirrigated than on irrigated cropland.

The stability of the coefficients for irrigated cropland $\left(\mathrm{X}_{4}\right)$ and output increasing operating expense $\left(\mathrm{X}_{8}\right)$ over the three years for which the analysis was conducted give one confidence that the same relationships may hold for at least a limited period in the future. On the other hand, the standard errors of estimate and the standard errors of the regression coefficients, while relatively small, indicate that the results do not hold with quite the same precision for the limited irrigation counties as for the major irrigation counties.

In interpreting the results of the analysis, for both the major irrigation counties and the limited irrigation counties, it will be well to remember that the regression coefficients obtained for each of the input categories reflect not just the marginal contribution to output of each input but rather the marginal contribution of each input plus a bundle of complementary inputs. In the case of irrigated and nonirrigated cropland, these complementary inputs include machinery and equipment investment, machinery operating expenses, and a substantial share of labor and other inputs. In the case of output-increasing operating expenses, the complementary inputs include specialized fertilizer and insecticide application equipment, some labor inputs, and other items. The problem of how to treat irrigated pasture and livestock investment remains ambiguous. Variations among counties in livestock investment and in the productivity of irrigated and nonirrigated pasture were so great that no meaningful statements can be made regarding the productivity of these inputs for the major irrigation counties as a whole. 


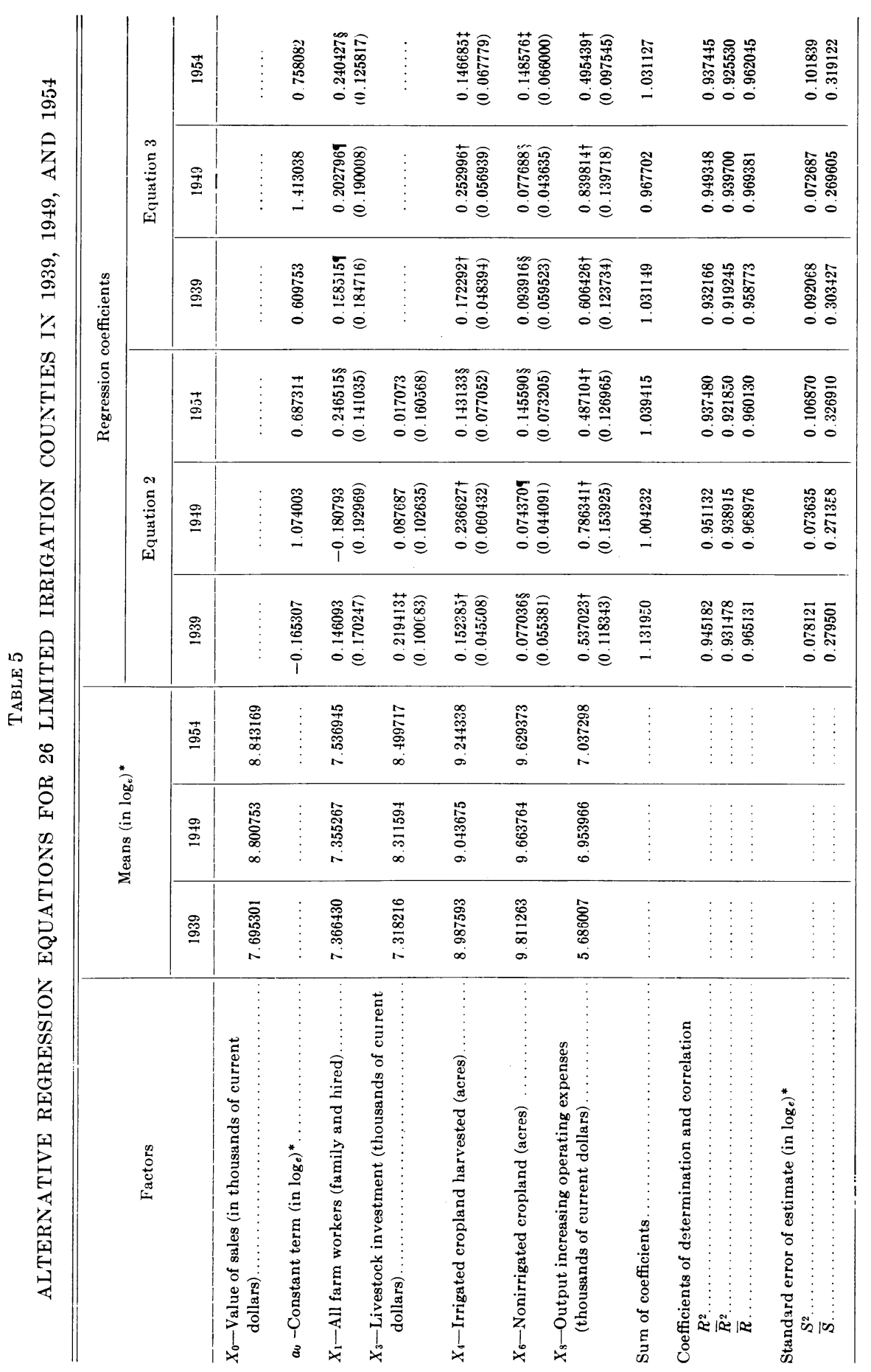




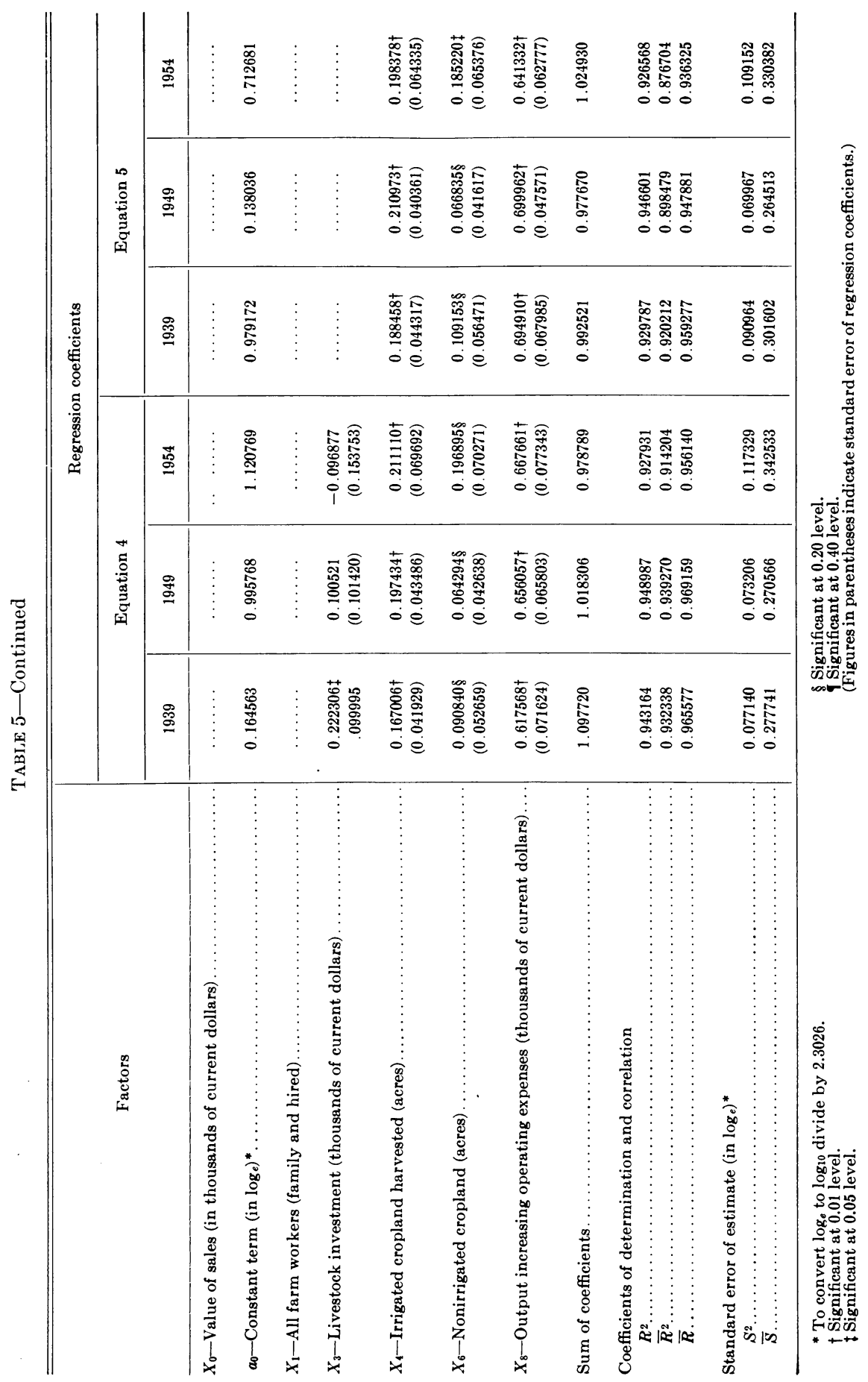


TABLE 6

COEFFICIENTS OF SIMPLE CORRELATION FOR LIMITED IRRIGATION COUNTIES, 1939, 1949, AND 1954

\begin{tabular}{|c|c|c|c|c|c|c|}
\hline \multirow{2}{*}{ Factors } & \multicolumn{6}{|c|}{ Coefficients of correlation } \\
\hline & $r_{0}$ & $r_{1}$ & $r_{3}$ & $r_{4}$ & $r_{6}$ & $r_{8}$ \\
\hline $\begin{array}{l}\text { 1954: } \\
\text { Value of sales } \ldots \ldots \ldots \ldots \ldots \ldots \ldots \ldots r_{0} \\
\text { All farm workers } \ldots \ldots \ldots \ldots \ldots \ldots r_{1} \\
\text { Livestock investment. } \ldots \ldots \ldots \ldots \ldots r_{3} \\
\text { Irrigated cropland harvested } \ldots \ldots \ldots \ldots r_{4} \\
\text { Non-irrigated cropland harvested } \ldots \ldots r_{6} \\
\text { Output increasing operating expense } \ldots r_{8}\end{array}$ & $\begin{array}{l}1.000000 \\
\ldots \ldots \ldots \\
\ldots \ldots \ldots \\
\ldots \ldots \ldots \\
\ldots \ldots \ldots \\
\ldots \ldots \ldots\end{array}$ & $\begin{array}{l}0.911759 \\
1.000000 \\
\ldots \ldots \ldots \\
\ldots \ldots \ldots \\
\ldots \ldots \ldots \\
\ldots \ldots \ldots\end{array}$ & $\begin{array}{l}\mathbf{0 . 7 1 9 9 0 6} \\
\mathbf{0 . 5 8 5 4 9 5} \\
1.000000 \\
\ldots \ldots \ldots \\
\ldots \ldots \ldots \\
\ldots \ldots \ldots\end{array}$ & $\begin{array}{l}0.344735 \\
0.342110 \\
0.368769 \\
1.000000 \\
\ldots \ldots \ldots \\
\ldots \ldots \ldots\end{array}$ & $\begin{array}{l}0.769189 \\
0.714747 \\
0.666760 \\
0.495009 \\
1.000000 \\
\ldots \ldots \ldots\end{array}$ & $\begin{array}{l}0.889040 \\
0.827071 \\
0.670469 \\
0.013807 \\
0.562717 \\
1.000000\end{array}$ \\
\hline $\begin{array}{l}\text { 1949: } \\
\text { Value of sales } \ldots \ldots \ldots \ldots \ldots \ldots \ldots \ldots r_{0} \\
\text { All farm workers } \ldots \ldots \ldots \ldots \ldots \ldots r_{1} \\
\text { Livestock investment. } \ldots \ldots \ldots \ldots \ldots r_{3} \\
\text { Irrigated cropland harvested } \ldots \ldots \ldots r_{4} \\
\text { Nonirrigated cropland harvested } \ldots \ldots r_{6} \\
\text { Output increasing operating expense } \ldots r_{8}\end{array}$ & $\begin{array}{l}1.000000 \\
\ldots \ldots \ldots \\
\ldots \ldots \ldots \\
\ldots \ldots \ldots \\
\ldots \ldots \ldots \\
\ldots \ldots \ldots\end{array}$ & $\begin{array}{l}0.924623 \\
1.000000 \\
\ldots \ldots \ldots \\
\ldots \ldots \ldots \\
\ldots \ldots \ldots \\
\ldots \ldots \ldots\end{array}$ & $\begin{array}{l}\mathbf{0 . 7 8 1 6 4 5} \\
\mathbf{0 . 7 2 2 0 7 8} \\
1.000000 \\
\ldots \ldots \ldots \\
\ldots \ldots \ldots \\
\ldots \ldots \ldots\end{array}$ & $\begin{array}{l}0.220141 \\
0.213732 \\
0.172795 \\
1.000000 \\
\ldots \ldots \ldots \\
\ldots \ldots \ldots\end{array}$ & $\begin{array}{l}0.666080 \\
0.655031 \\
0.510563 \\
0.352740 \\
1.000000 \\
\ldots \ldots \ldots\end{array}$ & $\begin{array}{r}0.911439 \\
0.906206 \\
0.725314 \\
-0.119594 \\
0.515538 \\
1.000000\end{array}$ \\
\hline $\begin{array}{l}\text { 1939: } \\
\text { Value of sales } \ldots \ldots \ldots \ldots \ldots \ldots \ldots \ldots r_{0} \\
\text { All farm workers } \ldots \ldots \ldots \ldots \ldots \ldots \ldots r_{1} \\
\text { Livestock investment. } \ldots \ldots \ldots \ldots \ldots r_{8} \\
\text { Irrigated cropland harvested } \ldots \ldots \ldots \ldots r_{4} \\
\text { Nonirrigated cropland harvested } \ldots \ldots r_{8} \\
\text { Output increasing operating expense } \ldots r_{8}\end{array}$ & $\begin{array}{l}1.000000 \\
\ldots \ldots \ldots \\
\ldots \ldots \ldots \\
\ldots \ldots \ldots \\
\ldots \ldots \ldots \\
\ldots \ldots \ldots\end{array}$ & $\begin{array}{l}0.911150 \\
1.000000 \\
\ldots \ldots \ldots \\
\ldots \ldots \ldots \\
\ldots \ldots \ldots \\
\ldots \ldots \ldots\end{array}$ & $\begin{array}{l}\mathbf{0 . 7 6 0 3 7 9} \\
\mathbf{0 . 6 6 0 4 9 6} \\
1.000000 \\
\ldots \ldots \ldots \\
\ldots \ldots \ldots \\
\ldots \ldots \ldots\end{array}$ & $\begin{array}{l}0.100880 \\
0.016696 \\
0.078318 \\
1.000000 \\
\ldots \ldots \ldots \\
\ldots \ldots \ldots\end{array}$ & $\begin{array}{l}0.771782 \\
0.745956 \\
0.582884 \\
0.096882 \\
1.000000 \\
\ldots \ldots \ldots\end{array}$ & $\begin{array}{r}0.912044 \\
0.900177 \\
0.660181 \\
-0.204227 \\
0.686223 \\
1.000000\end{array}$ \\
\hline
\end{tabular}

\section{RESOURCE PRODUCTIVITY ESTIMATES}

In tracing the implications for irrigation development policy in California of the statistical analysis presented in the previous section, the first step is to examine the marginal value productivity estimates for the several input categories. Table 7 presents such estimates calculated from the production functions presented in the previous section. Estimates based on an arithmetically linear regression equation are also presented. A more detailed presentation of the results of the arithmetic regression is given in Appendix A.

\section{The Productivity Estimates}

In the major irrigation counties, the marginal value productivity of irrigated cropland was slightly less than $\$ 150.00$ per acre in both 1949 and 1954, estimated at either the geometric or the arithmetic mean. This was a rise from less than $\$ 50.00$ per acre in 1939 . In 1939 and in 1949 average marginal and marginal value productivities of irrigated cropland were similar. In 1954, however, the marginal value productivity of irrigated cropland was considerably lower than the average marginal value productivity of irrigated cropland.

Examination of selected California cost and return studies indicates that a marginal return of $\$ 147.36$ is barely sufficient to cover annual charges for land, water and complementary inputs (i.e., labor, machine operating ex- 


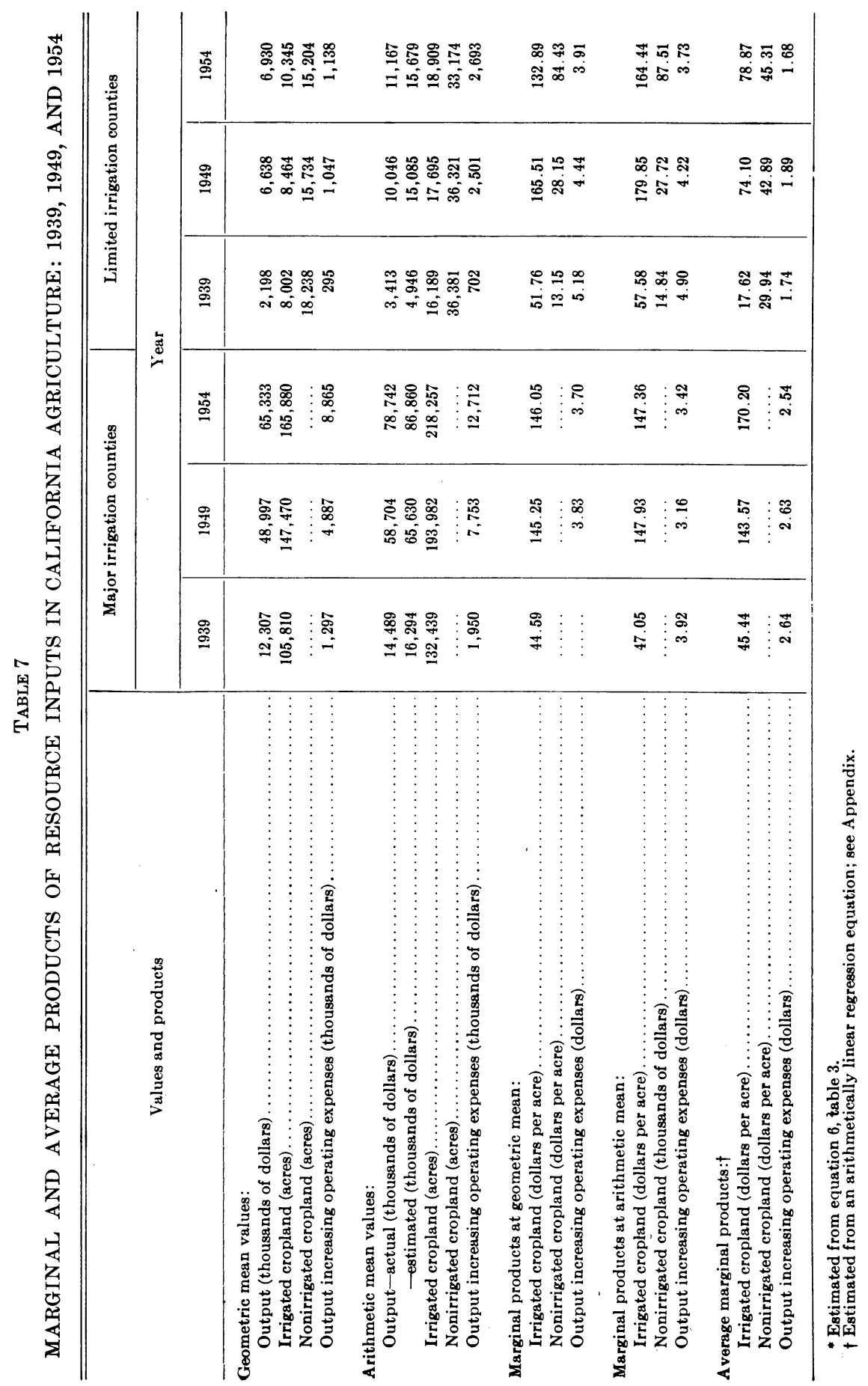


pense and interest and depreciation on machinery investment) even in the case of extensive crops such as rice and alfalfa.

The marginal value productivity of output increasing operating expenses, estimated at the geometric mean, declined from $\$ 4.47$ per dollar of expenditure in 1939 to $\$ 3.70$ per dollar of expenditure in 1954 . The estimates at the arithmetic mean ran somewhat below the estimates at the geometric mean during all three years, and the average marginal value productivity estimates ran well below both marginal value productivity estimates. The return per dollar expenditure on output increasing operating expenses was quite favorable in all three years regardless of the measure used.

In the limited irrigation counties, the marginal value productivity of irrigated cropland reached its highest level in 1949. In contrast to the close agreement between estimates of the marginal productivities at the arithmetic and geometric means in the major irrigation counties, the estimates at the geometric mean consistently ran well below the estimates of the arithmetic mean in the limited irrigation counties. Furthermore, the average marginal value productivity estimates in the counties with limited irrigation were far below the marginal value productivity estimates. The greater divergence between the several sets of estimates in the limited irrigation counties apparently reflects the greater diversity of soil and climatic conditions among these counties. As in the case of the major irrigation counties, the marginal value productivity estimates are not high relative to cost estimates from available cost and returns studies.

The two marginal value productivity estimates for nonirrigated cropland show rather close agreement throughout the period. The average marginal value productivity estimates ran well below the marginal estimates. As indicated in the discussion of the productivity coefficients in the previous section, there is some basis for expecting that the marginal value productivity estimates for nonirrigated cropland for 1954 are above normal expectations.

The marginal value productivity of output increasing operating expenses, estimated at the geometric mean, was slightly above the estimates at the arithmetic mean throughout the period; both estimates ran far above the average marginal value productivity estimates. The very large difference between the average estimates and the two marginal estimates probably reflects the high marginal productivity of output increasing operating expenses in those few counties in the limited irrigation group which have a high ratio of irrigated cropland to other land and, conversely, a much lower marginal productivity of output increasing operating expenses in a larger group of limited irrigation counties where the ratio of irrigated cropland to other land is extremely low.

\section{Specification Bias in the Productivity Estimates}

Before discussing certain implications of the productivity estimates presented in table 7 it seems desirable to consider the extent to which those estimates may be subject to specification bias. The possibility of substantial bias is suggested by the very high marginal productivity estimates for output increasing operating expenses, particularly in the limited irrigation counties.

One method of estimating the extent of such bias is by comparing the 
marginal productivity estimates presented in table 7 with other marginal productivity estimates computed using the productivity coefficients from an equation which included variables which were excluded from equations 5 (limited irrigation counties) and 6 (major irrigation counties). In table 8 the 1954 marginal productivity estimates for irrigated and nonirrigated cropland, and the output increasing operating expense computed using the coefficient from equation 3 (major and limited irrigation counties) are compared with the 1954 coefficients from table 7 . The results presented in table 8 imply relatively minor specification bias in the major irrigation counties. In the limited irrigation counties, however, the possibility of substantial specification bias is suggested.

COMPARISON OF ALTERNATIVE MARGINAL PRODUCTIVITY ESTIMATES FOR CALIFORNIA COUNTIES, 1954

\begin{tabular}{|c|c|c|c|c|}
\hline \multirow{2}{*}{ Marginal productivities } & \multicolumn{2}{|c|}{$\begin{array}{c}\text { Major irrigation } \\
\text { counties }\end{array}$} & \multicolumn{2}{|c|}{$\begin{array}{l}\text { Limited irrigation } \\
\text { counties }\end{array}$} \\
\hline & Equation 6 & Equation 3 & Equation 5 & Equation 3 \\
\hline \multicolumn{5}{|l|}{ Marginal productivities at geometric mean: } \\
\hline Irrigated cropland (dollars per acre)....... & 146.05 & 137.30 & 132.89 & 98.26 \\
\hline Nonirrigated cropland (dollars per acre) $\ldots \ldots \ldots \ldots \ldots$ & $\ldots \ldots$ & $\ldots \ldots$ & 84.43 & 67.72 \\
\hline Output increasing operating expenses (dollars per dollar)... & 3.70 & 3.33 & 8.91 & 3.02 \\
\hline \multicolumn{5}{|l|}{ Marginal productivities at arithmetic mean: } \\
\hline Irrigated cropland (dollars per acre)........ & 147.36 & 138.73 & 164.44 & 123.13 \\
\hline Nonirrigated cropland (dollars per acre) $\ldots \ldots \ldots \ldots \ldots \ldots$ & $\ldots \ldots$ & $\ldots \ldots$ & 87.51 & 70.22 \\
\hline Output increasing operating expenses (dollars per dollar)... & 3.42 & 3.09 & 3.73 & 2.88 \\
\hline
\end{tabular}

The differences between the two sets of estimates presented in table 8 may overestimate the extent to which specification bias is present. The lower estimates of the marginal productivity of current operating expenses are, however, not out of line with the results of recent work at the USDA. Ibach and Lindberg (1958) have estimated the marginal productivity of fertilizer at $\$ 2.93$ for the United States as a whole in 1954 . Their calculations for major crop groups show marginal productivities of $\$ 3.40$ for all intertilled crops and $\$ 1.96$ for close growing crops. These high marginal productivities for output increasing operating expenses, both in California and in agriculture generally, apparently reflect a continuing short run disequilibrium stemming from technological change channeled into agriculture through the purchase of current operating expense items.

The above analysis does suggest the desirability of considerable caution in using the marginal productivity estimates computed for the limited irrigation counties. For some purposes it may be desirable to compare the results obtained from using equation 5 with the results from using equation 3 . In the major irrigation counties the only modification suggested is that when equation 6 is used the equilibrium return on investment in current operating expenses should probably not be expected to fall below $\$ 1.30-\$ 1.40$ per dollar spent. 


\section{Some Implications of the Productivity Estimates}

The marginal value productivity estimates presented in tables 7 and 8 would seem to indicate that the increase in the value of farm sales from small additions to irrigated cropland would be only slightly less in the limited irrigation counties than in the major irrigation counties. Whenever moderate increments to irrigated acreage (as compared to the large increase envisaged under the California Water Plan) are being considered, however, the relative advantage of the major irrigation counties tends to increase. This is based on two factors: First, additions to the output of irrigated cropland

TABLE 9

AVERAGE IMPACT OF INCREASE IN IRRIGATED CROPLAND HARVESTED ON VALUE OF SALES IN MAJOR IRRIGATION COUNTIES AND LIMITED IRRIGATION COUNTIES

\begin{tabular}{|c|c|c|c|c|}
\hline Status change by method & $\begin{array}{c}\text { Value of } \\
\text { sales }\end{array}$ & $\begin{array}{l}\text { Irrigated } \\
\text { cropland } \\
\text { harvested }\end{array}$ & $\begin{array}{l}\text { Nonirrigated } \\
\text { cropland } \\
\text { harvested }\end{array}$ & $\begin{array}{l}\text { Output } \\
\text { increasing } \\
\text { operating } \\
\text { expenses }\end{array}$ \\
\hline Major irrigation county: & dollars & acres & acres & dollars \\
\hline Before irrigation development. & $65,333,000$ & 165,880 & 34,973 & $8,865,000$ \\
\hline After irrigation development... & $66,770,000$ & 175,880 & 29,973 & $8,865,000$ \\
\hline Change with irrigation development. & $+1,437,000$ & $+10,000$ & $-5,000$ & $\mathbf{0}$ \\
\hline Limited irrigation county: & & & & \\
\hline Before irrigation development & $6,930,000$ & 10,345 & 15,204 & $1,138,000$ \\
\hline After irrigation development... & $7,358,000$ & 20,345 & 10,204 & $1,138,000$ \\
\hline Change with irrigation development. . & $+428,000$ & $+10,000$ & $-5,000$ & $\mathbf{0}$ \\
\hline
\end{tabular}

in the limited irrigation counties must, typically, come in substantial part from nonirrigated cropland where marginal value productivities were fairly high, even in years other than 1954. In the major irrigation counties, much of the increase in irrigated cropland could come at the expense of other land which, as indicated by the productivity coefficient for nonirrigated cropland, contributes only minor inerements to the value of sales. In many areas, such as the west side of the San Joaquin Valley, the land is too dry to be used for any productive purpose at present. Second, the marginal value productivity of irrigated cropland in the limited irrigation counties tends to drop off much more rapidly from given (absolute) increases in irrigated acres. These points can perhaps best be illustrated by an example. Hypothetical "typical" counties will be selected by taking the geometric mean values for each area.

Assume that a choice is being made between adding 10,000 acres of irrigated cropland in one of the major irrigation counties or in one of the limited irrigation counties. Assume also that half of the additional 10,000 acres of irrigated cropland would come from nonirrigated cropland and the other half from nonirrigated pasture. (An alternative way of setting up the illus- 
tration would be to add the 10,000 acres of irrigated cropland, distributed in approximately the same geographic pattern as existing irrigated cropland, to the entire set of counties in each area.)

By combining the input data before and after irrigation development with equation 6 in table 3 and equation 5 in table 5 , the value of sales in each period and the change in the value of sales between periods can be computed. The results of this computation are presented in table 9 .

The data in table 9 indicate that on the average the 10,000-acre increase in irrigated cropland in the major irrigation county would be accompanied by an estimated net increase in farm sales roughly 3.3 times as large as in the limited irrigation counties. If equation 3 in table 5 had been used,

TABLE 10

EFFECT OF SUBSTITUTION OF IRRIGATED CROPLAND AND OUTPUT INCREASING OPERATING EXPENSES

\begin{tabular}{|c|c|c|c|c|}
\hline Status change by method & $\begin{array}{l}\text { Value of } \\
\text { sales }\end{array}$ & $\begin{array}{l}\text { Irrigated } \\
\text { cropland } \\
\text { harvested }\end{array}$ & $\begin{array}{c}\text { Nonirrigated } \\
\text { cropland } \\
\text { harvested }\end{array}$ & $\begin{array}{c}\text { Output } \\
\text { increasing } \\
\text { operating } \\
\text { expenses }\end{array}$ \\
\hline Effect of adding irrigated cropland: & dollars & acres & acres & \\
\hline Before irrigation development... & $65,333,000$ & 165,880 & 34,973 & $8,865,000$ \\
\hline After irrigation development. . . & $66,770,000$ & 175,880 & 29,973 & $8,865,000$ \\
\hline Change with irrigation development.. & $+1,437,000$ & $+10,000$ & $-5,000$ & 0 \\
\hline Substitution of output increasing operating expense: & & & & \\
\hline Before substitution $\ldots \ldots \ldots \ldots \ldots \ldots \ldots \ldots \ldots$ & $65,333,000$ & 165,880 & 34,973 & $8,865,000$ \\
\hline After substitution $\ldots \ldots \ldots \ldots \ldots \ldots \ldots \ldots$ & $66,770,000$ & 165,880 & 34,973 & $9,257,000$ \\
\hline Change with substitution $\ldots \ldots \ldots \ldots \ldots \ldots \ldots$ & $+1,437,000$ & 0 & 0 & $+392,000$ \\
\hline
\end{tabular}

the ratio would show an even greater advantage for the major irrigation counties. Note that these are average results. Comparisons between some actual counties would result in a somewhat lower ratio, and comparisons among other actual counties would result in a greater advantage for the major irrigation counties.

In spite of the relative stability of the coefficients for irrigated cropland harvested and for output increasing operating expenses year to year, variations in the more unstable coefficient for nonirrigated cropland harvested can also affect the ratio. If, for example, in a dry year the coefficient for nonirrigated cropland harvested fell to the relatively low level of 1949 (see table 5) the average advantage for counties in the major irrigation area would decline to approximately 2.0 .

The same type of example can be employed to estimate how large a rise in output increasing current operating expenses would be required to match the increase in value of sales obtained by adding a given number of acres of irrigated cropland. In the previous illustration the average effect of increased acres of irrigated cropland was obtained by holding output increasing current operating expenses unchanged and making all the adjustments in land in- 
puts. In this example, land inputs are held unchanged and output increasing operating expenses are varied. The example presented below is based on the same hypothetical "typical" major irrigation county used in the previous example. Results of this comparison, presented in table 10, indicate that the same average annual increase in value of sales, $\$ 1,437,000$, obtained by adding 10,000 acres of irrigated cropland could be obtained by an increase in output increasing operating expenses of $\$ 392,000$. This is an increase of approximately $\$ 3.67$ in value of sales for each additional dollar of output increasing operating expenses. Addition of the costs of complementary inputs and/or adjustment for specification bias would reduce this magnitude somewhat.

Another way of viewing the comparisons presented in table 9 is to consider the fact that $\$ 392,000$ represents the opportunity cost of achieving an annual increase in output of $\$ 1,437,000$ in a "typical" county in the major irrigation area by adding 10,000 acres of irrigated cropland. If the annual charges per acre for water (tolls and assessments) plus the cost of inputs complementary to irrigated land exceed $\$ 39.20$ per acre, the increase in output can be obtained at lower cost by increasing the use of output increasing operating expenses rather than by adding acres of irrigated cropland. Available cost and return studies indicate that by and large $\$ 39.20$ would rarely be sufficient to cover land and water costs let alone the costs of complementary inputs.

\section{RESOURCE INPUTS AND FARM OUTPUT IN 1980}

The California Department of Water Resources has projected an ultimate net irrigated area (excluding lands having rights in and to the waters of the Colorado River) of approximately 16.25 million acres. Addition of lands currently being irrigated from the Colorado River raises this level to approximately 16.7 million acres; this estimate compares to California Department of Water Resources estimates of approximately 6.9 million net irrigated acres in the early 1950's (California Water Resources Board, 1955), and to Census of Agriculture estimates of slightly more than 7.0 million acres in 1954. Not all of these additional irrigated acres will be brought into production by 1980. No firm estimates for that year are available, although a figure of about 13.75 million acres has been suggested (California Water Resources Board, 1955).

An estimate of the distribution of this total between the major and limited irrigation counties and between irrigated cropland and irrigated pasture is presented in table 11. Estimates of the distribution of irrigated land between major and limited irrigation counties, and between irrigated cropland and pasture, are based on data presented in Bulletin 2 of the California State Water Resources Board. Lands identified in Bulletin 2 as requiring supplemental water to replace currently depleting ground water supplies are included in development stage 1 . The valley mountain land and high desert lands which are less productive or which cost more to develop were included in stage 3. In order for irrigation development to reach the projected level of 13.75 million acres, it will be necessary to develop all of the land included in stages 1 and 2 , as well as slightly more than two million acres of the land identified in stage 3 . 


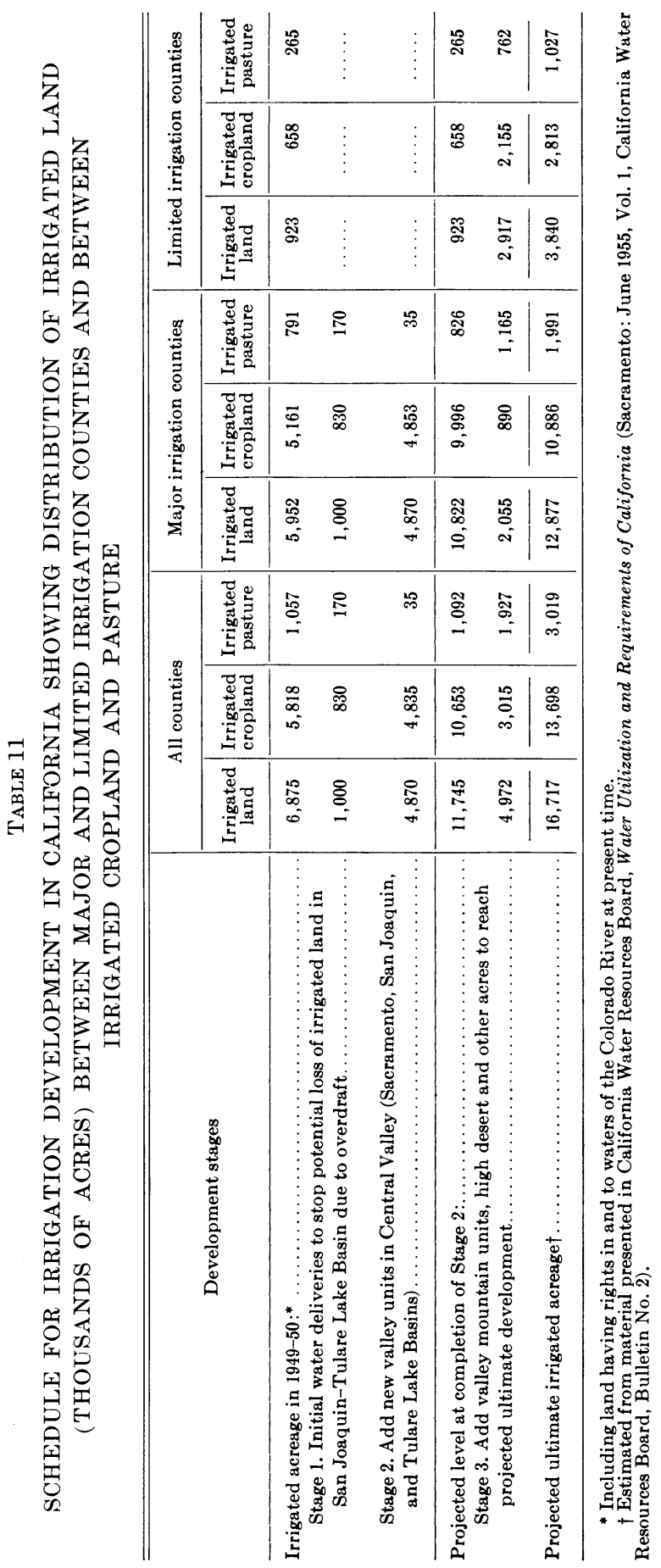




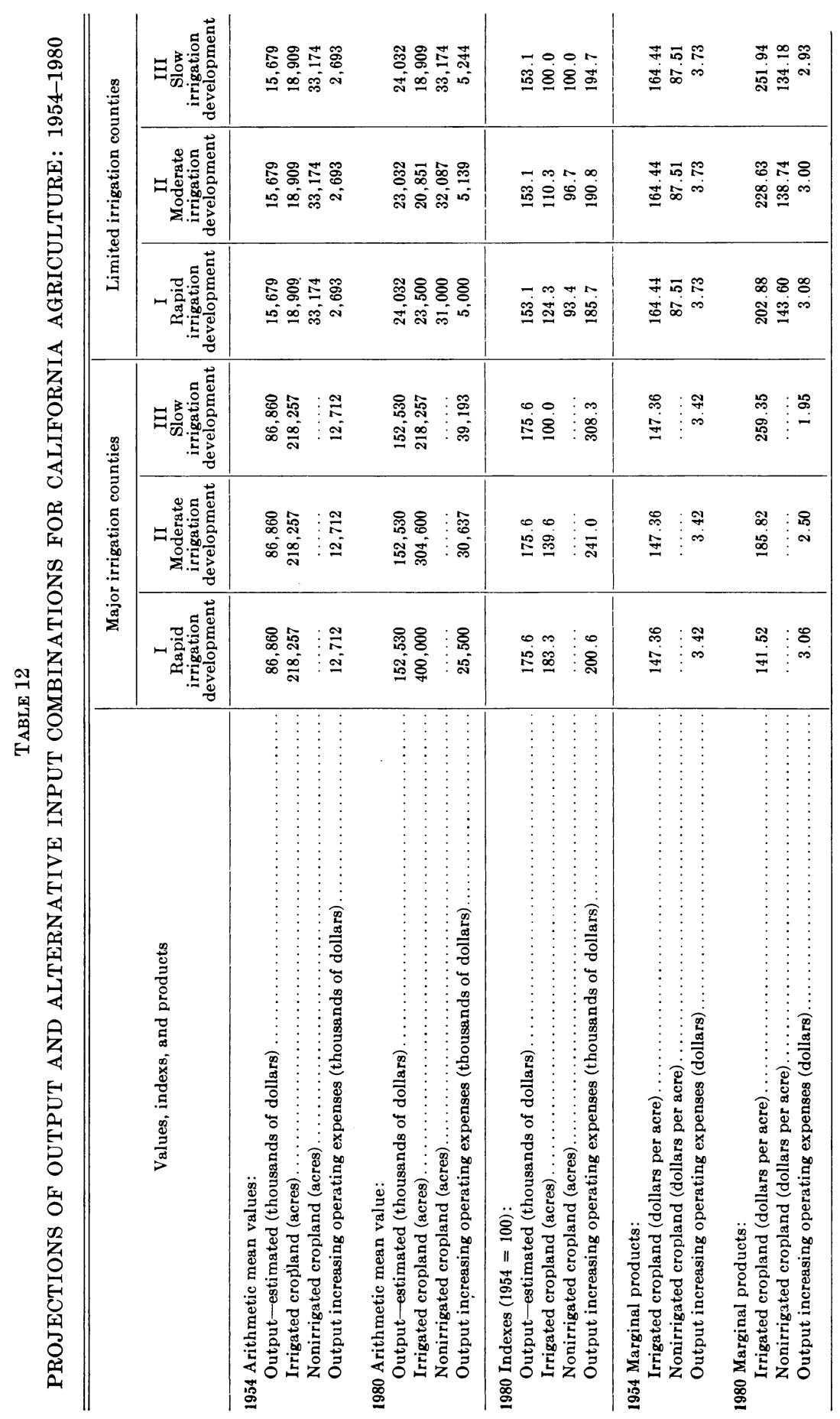


The production functions previously developed will be used in this section to estimate the output which would result.from increases in irrigated cropland by amounts roughly comparable to the levels of irrigation development postulated at the end of stage 2. Estimates of alternative input combinations that would result in the same level of output are also presented.

Although somewhat similar approaches have been employed in the past, (Swanson, 1956; Ruttan, 1956; Bhattacharjee, 1955) there is always considerable criticism of use of the Cobb-Douglas approach for estimating output or marginal productivities when inputs depart sharply from the geometric mean values (Haver, 1956 ; Wantrup, 1959) ; in this case two defenses can be offered: (1) The coefficients for irrigated cropland and output increasing operating expenses did not change significantly (at the 5 per cent level) between 1939 and 1954 in the major irrigation counties, (equation 6, table 3), or in the limited irrigation counties (equation 5, table 5). Stability of these coefficients for the 15-year period between 1939 and 1954 does not imply continued stability in the future. However, it is noteworthy that the coeffcients for irrigated cropland and output increasing operating expenses remained relatively stable during a period of substantial irrigation development. The entire Central Valley project, for example, has been brought into operation during the period covered by the analysis without resulting in any statistically significant change in the coefficients. Furthermore, technological development proceeded at perhaps the fastest rate in California history during this period. Thus, it is reasonable to assume that the relationships described by equation 6 in table 3 and equation 5 in table 5 will not shift radically unless fairly drastic changes occur. (2) The projections for the typical irrigation county do not actually exceed the range observed among major irrigation counties in 1954. Examination of the relationship between actual and projected values of farm output among major and limited irrigation counties does not reveal any tendency for the large counties to depart from the estimated relationship. (See Appendix, figs. A1 and A2.)

The following assumptions were employed in constructing model $\mathrm{I}$ in table 12. In the major irrigation counties it was assumed that irrigated cropland would rise to the level projected at the completion of stage 2 in table 11 . In the limited irrigation counties it was assumed that the same number of acres per year of irrigated cropland would be added between 1954 and 1980 as between 1939 and 1954. It was also assumed for the limited irrigation counties that half of the increase in acres of irrigated cropland would come from nonirrigated cropland, thus resulting in a continued decline in nonirrigated cropland in the limited irrigation counties. In both the major irrigation counties and the limited irrigation counties it was assumed that output increasing operating expenses would continue to rise by the same average amount per year as during the 1939-1954 period, with adjustments made for price changes.

Table 12 shows the implications of these assumptions for input changes in the hypothetical "typical" county in both the major and limited irrigation areas. Output estimates for 1980 were obtained by inserting the projected input levels into equation 6 (table 3 ) for the major irrigation counties and into equation 5 (table 5 ) for the limited irrigation counties. 
The estimated level of output in 1980 obtained from the projected input levels in the major irrigation counties is 75.6 per cent higher than the 1954 level, estimated with inputs at the arithmetic mean values. The shift in input combinations used to produce the increased output resulted in only modest declines in the estimated marginal value productivity of both irrigated cropland and output increasing operating expenses between 1954 and 1980.

In the limited irrigation counties the result for 1980 was a level of output 53.1 per cent higher than the 1954 level, estimated with inputs at the arithmetic mean values. The shift in input combinations used to produce the increased output resulted in rather substantial increases in the estimated marginal value productivities for the two land categories and a substantial decline in the marginal value productivities for output increasing operating expenses.

The assumptions employed in model I imply a rather rapid rate of irrigation development. In model III an attempt was made to determine the quantity of current inputs that would be required to produce the same increase in farm output as in model I if irrigation development is limited to the level of stage 1 (table 10). This implies that irrigation development proceeds only fast enough to prevent land now irrigated from ground water sources from going out of irrigated production because of lowering of ground water levels.

This result could be achieved by approximately tripling the output increasing operating expenses in the major irrigation counties, and by approximately doubling the output increasing operating expenses in the limited irrigation counties. In spite of these large increases, the marginal value productivity of output increasing operating expenses would remain relatively high-at $\$ 1.95$ per dollar of expenditures in the major irrigation counties and at $\$ 2.93$ per dollar of expenditures in the limited irrigation counties.

Model II, which stands in a position intermediate to models I and III, was constructed to produce estimates of the output increasing operating expenses and acres of irrigated cropland that would result in a marginal value productivity of $\$ 2.50$ per dollar of expenditures on output increasing operating expenses in the major irrigation counties and of $\$ 3.00$ in the limited irrigation counties, and the same increase in output as in models I and III.

As the input combination is shifted away from that posited in model I and toward that posited in model III, the profitability of irrigation development increases. When marginal value productivities are at the levels estimated for the major irrigation counties in model I, annual charges for water (tolls and assessments) plus the costs of inputs complementary to irrigated land must fall below $\$ 47.11$ per acre if additional expenditure for irrigation is to be more profitable than expenditures on the output increasing operating expenses. In model III, on the other hand, irrigation represents the lowest cost method of increasing output as long as annual charges for water (toll plus assessment) plus the costs of complementary inputs are less than $\$ 133.00$ per acre.

There is, of course, some possibility that technological change, reflected in 
the constant term in the production functions employed above, might raise the level of output obtained from the projected input levels above the output levels projected in table 12. It seems likely, for example, that the shift in the constant term of equation 6 (table 3) from 1.606228 in 1939 to 2.064084 in 1954 reflected a combination of higher price levels and increased efficiency in converting inputs to outputs. $\Lambda \mathrm{n}$ attempt was made to eliminate the impact of higher factor and product prices by converting 1939 dollar values to 1954 dollar values and rerunning equations 6 (table 3 ) and 5 (table 5). The results are presented in Appendix Table A-3.

This procedure resulted in practically identical constant terms in 1939 and 1954 for the major irrigation counties, indicating that the rise in the constant term was primarily due to changes in the price level when input and output data were not adjusted for price changes. For the limited irrigation counties the constant term in equation 5 is higher in 1939 than in 1954 regardless of whether actual dollar or adjusted dollar values are used. Therefore this analysis does not provide any basis for projecting higher output levels from the projected input levels on the basis of technological change.

This conclusion appears to be inconsistent with other work which indicates that technological change has caused an increase in the constant term of the aggregate agricultural production function, in the three states of the Pacific region, from an index of 1.00 in 1938-1940 to an index of 1.40 in 1953-1955 (Stout and Ruttan, 1958). This inconsistency is partially removed when equations 2 and 3 (table 3 ), which contain a more complete set of inputs, are computed with adjusted rather than actual dollar values (not shown). In these two equations the constant term of the equations for 1939, computed with adjusted dollar values, remains below the constant term in the equations for 1954. Apparently the increased efficiency in resource use has been reflected in relative declines in inputs which are assumed to be complementary to the inputs included in equations 6 (table 3 ) and 5 (table 5).

When the projected output increases in the major and limited irrigation counties are combined, the projected index of output for the entire state stands at $169(1954=100)$. There is of course no particular reason why this figure should be approached or why it should not be exceeded. In 1953-55 the index of agricultural production stood at 210, relative to 1928-1930 (Beringer, 1959). Current estimates indicate that farm output requirements for the nation as a whole are expected to rise from a 1954 index of 100 to approximately 165 by 1980 . The exact amount will depend on the particular population levels that are eventually reached (see Appendix, table 3 ). The index of 169 , which our projections imply, is therefore somewhat higher than the increase expected from the nation as a whole during the quarter decade covered by the projections, but it is well below the gain made by California agriculture during the preceding quarter century.

The three projections presented in table 12 are, in a manner, intended to illustrate a range of possible alternatives. In figure 2, the same alternatives are presented graphically for the major irrigation counties. Isoquants re-

\footnotetext{
${ }^{5}$ Coefficients in the production function employed by Stout and Ruttan were computed using the factor share rather than a regression technique.
} 
flecting the marginal rates of substitution between irrigated cropland and output increasing operating expenses for the 1954 geometric mean values of output, the 1954 arithmetic mean values, and the projected 1980 arithmetic mean values, are presented. Scale lines are plotted for projection I $\left(b^{\prime}\right)$ and projection III $\left(c^{\prime} c^{\prime}\right)$.

The scale line for projection I emphasizes the close relationship between the assumptions regarding the marginal rates of substitution (MRS) between irrigated cropland and output increasing operating expenses assumed to

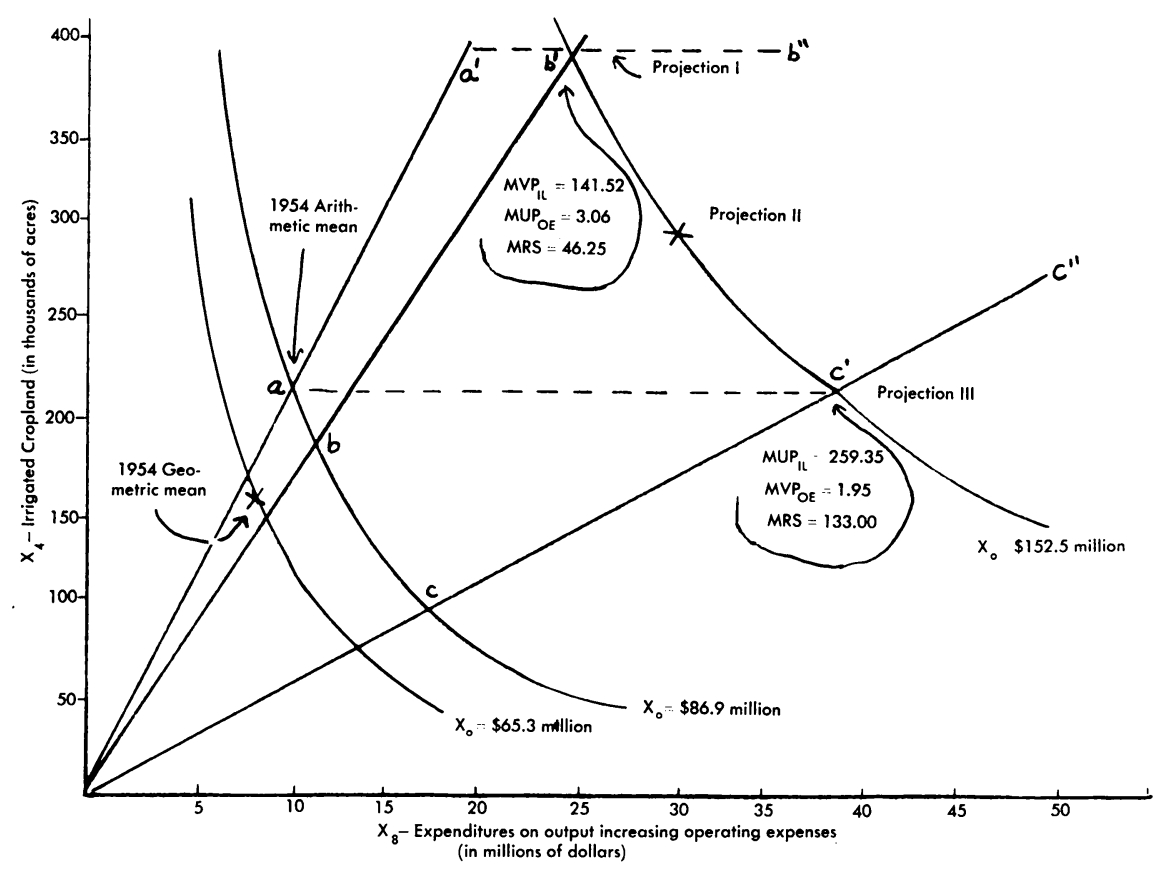

Fig. 2. Iso-product curves for irrigated cropland and output increasing operating expenses in "Typical" major irrigation county.

prevail in 1980 and the actual marginal rates of substitution which prevailed in 1954. It seems reasonable to expect that the marginal rate of substitution will continue to rise as farmers expand their use of output increasing operating expenses. There is no way of knowing whether the marginal rate of substitution will decline to the level of projection III by 1980 . The $\$ 1.95$ figure assumed in model III for all output increasing current operating expenses probably approximates the lower end of the range within which the marginal value productivity of output increasing current operating expenses can be expected to fall, given the extent of specification bias that may be present in the estimates.

Levels of output other than the projected level of 152.5 million dollars assumed in table 12 can also be employed. If we can accept 400,000 acres as the average upper limit and 218,000 acres (the 1954 arithmetic mean) as 
the lower limit in the average county in the major irrigation area, then any output level and input combination within the area $c^{\prime \prime} c^{\prime} a a^{\prime} b^{\prime \prime}$ should be feasible.

At any point in this area the marginal rate of substitution between fertilizer and irrigated cropland will be at least as high at the value calculated for 1954 at the arithmetic mean of $\$ 39.47$. Given the low marginal rate of substitution implicit in projection I there seems little doubt that the actual input combination for 1980 will be somewhere in the region to the right of $\mathbf{a} \mathbf{a}^{\prime}$.

A similar graphic illustration could be constructed for the limited irrigation counties. The lack of precision in results for those counties would make any such illustration less meaningful than the illustration presented for the major irrigation counties. Because the major share of increased output in California agriculture will in all probability come from the counties classified in major irrigation areas, attention has been centered on these counties.

\section{SUMMARY AND CONCLUSIONS}

It is important to reemphasize the following points:

1. During the three years studied the major possibilities of input substitution in California agriculture have been between irrigated cropland and output increasing operating expenses. Other inputs enter the production process only as complements to these two, or else vary in productivity to such an extent that meaningful coefficients cannot be established for the geographic areas considered.

2 . The marginal rates of substitution between irrigated cropland and output increasing operating expenses would indicate that the ratio of output increasing operating expenses to acres of irrigated cropland can be expected to rise regardless of the rate at which additional irrigated cropland is brought into production. Even though the marginal cost of adding irrigated cropland may in some instances be lower than marginal returns, at present it appears that increased output can be obtained at lower cost by increasing operating expenses rather than by adding acres of irrigated cropland.

3. Even if irrigated cropland acreage remains close to 1954 levels between now and 1980, it should be possible for agricultural output in California to expand more rapidly than projected national output requirements and still hold the computed marginal value product of output increasing operating expenses at near $\$ 2.00$ per dollar of expenditure. If irrigated cropland is increased to levels anticipated under the California Water Plan any substantial rise in use of output increasing operating expenses relative to acres of irrigated cropland will increase California farm output more than projected national output requirements. 


\section{LITERATURE CITED}

BERINGER, Christoph

1961. An economic model for determining the production function for water in agriculture, University of California, Berkeley, Giannini Foundation Research Report 240.

BhattacharJee, Jyoti P.

1955. Resource use and productivity in world agriculture. Jour. Farm Econ. 1:57-71.

Blaney, HARRY F., and WAYNe D. CRIDDLE

1947. A method of estimating water requirements in irrigated areas from climatological data. USDA Soil Conservation Service. December. 1-3.

BRONFENBRENNER, C. M.

1944. Production functions: Cobb-Douglas Interfirm, Intrafirm. Econometrica 12:3544.

California Water Resources Board

1955. Water utilization and requirements of California. California Water Res. Bd. Bul. 2.

Durand, David

1937. Some thoughts on marginal productivity with special reference to Professor Douglas' analysis. Jour. Political Economy 45:740-58.

Fortier, SAMUel, and ARThuR A. Young

1933. Irrigation requirements of the arid and semiarid lands of the Pacific Slope Basin. USDA Tech. Bul. 379:1.

Fox, KarL A., and JAMES F. CoONeY

1954. Effects of intercorrelation upon multiple correlation and regression measures. U. S. Agricultural Marketing Service.

GRILICHES, Zvi

1957. Specification bias in estimates of production functions. Jour. Farm Econ. 27: $8-20$.

Griliches, Zvi, and Yehuda Grenfeld

1960. Is aggregation necessarily bad \& Rev. Econ. and Stat. 42(1) :1-13.

Haver, Cecil B.

1956. Economic interpretation of production function estimates. In Resource Productivity, Returns to Scale, and Farm Size by Earl O. Heady, Glenn L. Johnson, and Lowell S. Hardin (eds.). Ames, Iowa: Iowa State College Press, 146-50.

Hedges, Trimble R., and Warren R. Bailey

1952. Appraisal of California agricultural productivity capacity attainable in 1952. University of California, Davis, Giannini Foundation Mimeographed Report 130.

Hoch, IRVING

1957. Estimates of agricultural resource productivities combining time series and cross section data. (Ph.D. dissertation, University of Chicago.)

IBACH, D. B., and R. C. LINDBERG

1958. The economic position of fertilizer use in the United States. USDA Agricultural Information Bul. 202:7-8.

KLEIN, L. R.

1956. Macro-economics and the theory of rational behavior. Econometrica 14:93-108.

MARSCHAK, JACOB, and William H. ANDREWS, JR.

1944. Random simultaneous equations and the theory of production. Econometrica $12: 143-205$.

Parks, W. L.

1956. Methodological problems in agronomic research involving fertilizer and moisture variables. In Methodological Procedures in the Economic Analysis of Fertilizer Use Data. Ames, Iowa: Iowa State College Press, 113-33.

RutTan, Vernon W.

1956. The contribution of technological change to farm output, 1950-75. Rev. Econ. and Stat. $37(1): 61-69$.

Stockton, J. R., and L. D. DoneEn

1957. Factors in cotton irrigation. California Agriculture 11(4):16-17, 25. 
Stout, Thomas T., and Vernon W. RutTan

1958. Regional patterns of technological change in American agriculture. Jour. Farm Econ. $40(2): 196-207$.

SWANSON, EARL R.

1956. Determining optimum size of business from production functions. In Resource Productivity, Returns to Scale, and Farm Size by Earl O. Heady, Glenn L. Johnson, and Lowell S. Hardin (eds.). Ames, Iowa: Iowa State College Press.

TINTNER, GERHARD

1944. A note on the derivation of production functions from farm data. Econometrica $12: 26-34$.

W ANTRUP, CirIACY

1959. Conceptual problems in projecting the demand for land and water. University of California, Berkeley, Giannini Foundation Paper 176.

WeEks, David

1955. A preliminary projection of California crop patterns for estimating ultimate water requirements. In Water Utilization and Requirements of California. California Water Res. Bd. Bul. 2:231-56. 


\section{APPENDIX A-DATA AND SOURCES}

The data and sources of data used in the analysis of factors affecting the farm output in California are described below:

Output measures:

$\mathrm{X}_{0}$ Value of all farm products sold (in current dollars)

1939-U. S. Bureau of the Census, United States Census of Agriculture: 1945 (Washington: Govt. Print. Off., 1946), vol. I Statistics for Counties), part 33 (California). (Table 4, line 8. ${ }^{1}$

1949-U. S. Bureau of the Census, United States Census of Agriculture: 1950 (Washington: Govt. Print. Off., 1952), vol. I (Counties and State Economic Areas), part 33 (California). (Table 7, line 39.)

1954-U. S. Bureau of the Census, United States Census of Agriculture: 1954 (Washington: Govt. Print. Off., 1956), vol. I (Counties and State Economic Areas), part 33 (California). (Table 4, line 3.)

Labor input:

$\mathrm{X}_{1}$ All farm workers (number of family and hired workers)

1939-U. S. Bureau of the Census, Sixteenth Census of the United States: 1940 Agriculture (Washington: Govt. Print. Off., 1942), vol. I (First and Second State Reports), part 6 (Statistics for Counties). (Table 10, line 8.)

1949-U. S. Bureau of the Census, United States Census of Agriculture: 1950 (Washington: Govt. Print. Off., 1952), vol. I (Counties and State Economic Areas), part 33 (California). (Table 3, line 61.)

1954-U. S. Bureau of the Census, United States Census of Agriculture: 1954 (Washington: Govt. Print. Off., 1956), vol. I (Counties and State Economic Areas), part 33 (California). (Table 6, line 5.)

Capital inputs:

$\mathrm{X}_{2}$ Value of implements and machinery (in current dollars)

1939-U. S. Bureau of the Census, Sixteenth Census of the United States: 1940, Agriculture (Washington: Govt. Print. Off., 1942), vol. I (First and Second Series State Reports), part 6 (Statistics for Counties). (Table 1, line 70.)

Data on the value of implements and machinery have not been directly available from the Census of Agriculture since 1944. Estimates for 1949 and 1954 were constructed by means of a regression equation between the value of implements and machinery and the number of tractors on farms in 1945. From this relationship, 1949 and 1954 estimates of the value of implements and machinery were obtained by inserting the number of tractors on farms in 1949 and 1954 and adjusting resulting estimates by the price indexes shown in Table A-1. Sources of data used in this estimating procedure were as follows:

(1) Value of implements and machinery (in current dollars)

1944-U. S. Bureau of the Census, United States Census of Agriculture: 1945 (Washington: Govt. Print. Off., 1946), vol. I (Statistics for Counties), part 33 (California). (Table 1.1, line 44.)

(2) Number of tractors on farms

1944-U. S. Bureau of the Census, United States Census of Agriculture: 1945 (Washington: Govt. Print. Off., 1946), vol. I (Statisties for Counties), part 33 (California). (Table 1.2, line 38.)

${ }^{1}$ Table and line references throughout apply to county tables. 
1949-U. S. Bureau of the Census, United States Census of Agriculture: 1950 (Washington: Govt. Print. Off., 1952), vol. I (Counties and State Economic Areas), part 33 (California). (Table 3, line 30.)

1954-U. S. Bureau of the Census, United States Census of Agriculture: 1954 (Washington: Govt. Print. Off., 1956), vol. I (Counties and State Economic Areas), part 33 (California). (Table 5, line 64.)

(3) Value of specified classes of livestock on farms (in current dollars), $\mathrm{X}_{3}$ 1939-U. S. Bureau of the Census, United States Census of Agriculture: 1945 (Washington: Govt. Print. Off., 1946), vol. I (Statistics for Counties), part 33 (California). (Table 1.1, line 52.)

1949-U. S. Bureau of the Census, United States Census of Agriculture: 1950 (Washington: Govt. Print. Off., 1952), vol. I (Counties and State Economic Areas), part 33 (California). (Table 4.1, line 1.)

Data on the value of specified classes of livestock on farms are not reported for 1954. An estimate was constructed by use of a regression equation expressing the relationship between the value of specified classes of livestock on farms in 1949 and the numbers of the specified classes of livestock on farms in 1949. From this relationship, 1954 estimates of the value of specified classes of livestock were computed by inserting the livestock numbers reported in 1954 and adjusting the resulting estimates by the price indexes shown in Table A-1. Sources of data used in this estimating procedure were as follows:

(1) Number of cattle and calves

1949-U. S. Bureau of the Census, United States Census of Agriculture: 1950 (Washington: Govt. Print. Off., 1952), vol. I (Counties and State Economic Areas), part 33 (California). (Table 4.1, line 16.)

1954-U. S. Bureau of the Census, United States Census of Agriculture: 1954 (Washington: Govt. Print. Off., 1956), vol. I (Counties and State Economic Areas), part 33 (California). (Table 7.1, line 3.)

(2) Number of hogs and pigs four months old and older

1949-U. S. Bureau of the Census, United States Census of Agriculture: 1950 (Washington: Govt. Print. Off., 1952), vol. I (Counties and State Economic Areas), part 33 (California). (Table 4.1, line 60.)

1954-U. S. Bureau of the Census, United States Census of Agriculture: 1954 (Washington: Govt. Print. Off., 1956), vol. I (Counties and State Economic Areas), part 33 (California). (Table 7.1, line 43.)

(3) Number of horses and mules

1949-U. S. Bureau of the Census, United States Census of Agriculture: 1950 (Washington: Govt. Print. Off., 1952), vol. I (Counties and State Economic Areas), part 33 (California). (Table 4.1, line 6.)

1954-U. S. Bureau of the Census, United States Census of Agriculture: 1954 (Washington: Govt. Print. Off., 1956), vol. I (Counties and State Economic Areas), part 33 (California). (Table 7.1, line 36.)

(4) Number of sheep and lambs

1949-U. S. Bureau of the Census, United States Census of Agriculture: 1950 (Washington: Govt. Print. Off., 1952), vol. I (Counties and State Economic Areas), part 33 (California). (Table 7.1, line 56.)

1954-U. S. Bureau of the Census, United States Census of Agriculture: 1954 (Washington: Govt. Print. Off., 1956), vol. I (Counties and State Economic Areas), part 33 (California). (Table 7.1, line 56.) 
(5) Poultry (number of chickens four months old and older plus turkeys kept for breeding)

1949-U. S. Bureau of the Census, United States Census of Agriculture: 1950 (Washington: Govt. Print. Off., 1952), vol. I (Counties and State Economic Areas), part 33 (California). (Table 4.2, lines 7 plus 17.)

1954-U. S. Bureau of the Census, United States Census of Agriculture: 1954 (Washington: Govt. Print. Off., 1956), vol. I (Counties and State Economic Areas), part 33 (California). (Table 7.2, lines 7 plus 36.)

Land inputs:

$\mathrm{X}_{4}$ Irrigated cropland harvested (acres)

1939-U. S. Bureau of the Census, Sixteenth Census of the United States: 1940, Agriculture (Washington: Govt. Print. Off., 1942), vol. I (First and Second Series State Reports), part 6 (Statistics for Counties). (Table 1, line 15.)

1949-U. S. Bureau of the Census, United States Census of Agriculture: 1950 (Washington: Govt. Print. Off., 1952), vol. I (Counties and State Economic Areas), part 33 (California). (Table 1a, line 23.)

1954-U. S. Bureau of the Census, United States Census of Agriculture: 1954 (Washington: Govt. Print. Off., 1956), vol. I (Counties and State Economic Areas), part 33 (California). (Table 1a, line 25.)

$\mathrm{X}_{5}$ Irrigated pasture (acres)

1939-U. S. Bureau of the Census, Sixteenth Census of the United States: 1940, Agriculture (Washington: Govt. Print. Off., 1942), vol. I (First and Second Series State Reports), part 6 (Statistics for Counties). (Table 1, line 53.)

1949-U. S. Bureau of the Census, United States Census of Agriculture: 1950 (Washington: Govt. Print. Off., 1952), vol. I (Counties and State Economic Areas), part 33 (California). (Table 1a, line 25.)

1954-U. S. Bureau of the Census, United States Census of Agriculture: 1954 (Washington: Govt. Print. Off., 1956), vol. I (Counties and State Economic Areas), part 33 (California). (Table 1a, line 29.)

$\mathrm{X}_{6 ;}$ Nonirrigated cropland harvested (acres)

1939-U. S. Bureau of the Census, Sixteenth Census of the United States: 1940, Agriculture (Washington: Govt. Print. Off., 1942), vol. I (First and Second Series State Reports), part 6 (Statistics for Counties). (Table 1, line 15 minus $\mathrm{X}_{4}$.)

1949-U. S. Bureau of the Census, United States Census of Agriculture: 1950 (Washington: Govt. Print. Off., 1952), vol. I (Counties and State Economic Areas), part 33 (California). (Table 1, line 21 minus $\mathrm{X}_{4}$.)

1954-U. S. Bureau of the Census, United States Census of Agriculture: 1954 (Washington: Govt. Print. Off., 1956), vol. I (Counties and State Economic Areas), part 33 (California). (Table 1, line 20 minus $\mathrm{X}_{4}$ )

\section{$\mathrm{X}_{\tau}$ Nonirrigated pasture (acres)}

1939-U. S. Bureau of the Census, United States Census of Agriculture: 1945 (Washington: Govt. Print. Off., 1946), vol. I (Statistics for Counties), part 33 (California). (Table 1.1, line 36 minus $\mathrm{X}_{5}$.)

1949-U. S. Bureau of the Census, United States Census of Agriculture: 1950 (Washington: Govt. Print. Off., 1952), vol. I (Counties and State Economic Areas), part 33 (California). (Table 1, line 73 minus $\mathrm{X}_{5}$.)

1954-U. S. Bureau of the Census, United States Census of Agriculture: 1954 (Washington: Govt. Print. Off., 1956), vol. I (Counties and State Economic Areas), part 33 (California). (Table 1 , line 76 minus $\mathrm{X}_{\bar{s}^{*}}$ ) 


\section{Current inputs:}

\section{$\mathrm{X}_{\mathrm{s}}$ Output increasing operating expenses (current dollars)}

1939-U. S. Bureau of the Census, Sixteenth Census of the United States: 1940, Agriculture (Washington: Govt. Print. Off., 1942), vol. I (First and Second Series State Reports), part 6 (Statistics for Counties). (Table 10, line 39 (purchased feed) plus line 48 (fertilizer) plus line 51 (lime).)

1949-U. S. Bureau of the Census, United States Census of Agriculture: 1950 (Washington: Govt. Print. Off., 1952), vol. I (Counties and State Economic Areas), part 33 (California). (Table 3, line 75 (purchased feed only).)

1954-U. S. Bureau of the Census, United States Census of Agriculture: 1954 (Washington: Govt. Print. Off., 1942), vol. I (Counties and State Economic Areas), part 33 (California). (Table 6, line 45 (purchased feed) plus line 52 (fertilizer) plus line 57 (lime).)

\section{$\mathrm{X}_{9}$ Equipment operating expenses (current dollars)}

1939-U. S. Bureau of the Census, Sixteenth Census of the United States: 1940, Agriculture (Washington: Govt. Print. Off., 1942), vol. I (First and Second Series State Reports), part 6 (Statistics for Counties). (Table 10, line 43 (gasoline and oil only).)

1949-U. S. Bureau of the Census, United States Census of Agriculture: 1950 (Washington: Govt. Print. Off., 1952), vol. I (Counties and State Economic Areas), part 33 (California). (Table 3 , line 81 (gasoline and oil) plus line 71 (machine hire).)

1954-U. S. Bureau of the Census, United States Census of Agriculture: 1954 Washington: Govt. Print. Off., 1956), vol. I (Counties and State Economic Areas), part 33 (California). (Table 6, line 49 (gasoline and oil) plus line 31 (machine hire).)

\section{$\mathrm{X}_{10}$ Irrigation water applied (acre feet)}

1939-U. S. Bureau of the Census, United States Census of Agriculture: 1940 (Washington: Govt. Print. Off., 1942), vol. III (Irrigation of Agricultural Lands, The United States). (Table 1, line 18 (acres of irrigated land) multiplied by Table 1, line 71 (acre feet of water applied per irrigated acre).)

1949--U. S. Bureau of the Census, United States Census of Agriculture: 1950 (Washington: Govt. Print. Off., 1952), vol. III (Irrigation of Agricultural Lands, The United States). Table 2.1, line 7 (acres of irrigated land) multiplied by Table 2.4, line 66 (average acre feet of irrigation water delivered to all irrigation enterprises). For counties where data on average acre feet was omitted the 1939 figure was used.

1954-Data on acre feet of irrigation water delivered is not available for 1954. An estimate of acre feet of irrigation water applied was constructed by multiplying the average acre feet of irrigation water delivered as reported for $1949\left(\mathrm{X}_{4}\right.$ plus $\left.\mathrm{X}_{5}\right)$. For counties where data on average acre feet was plotted in the 1949 census, the 1939 figure was used.

$\mathrm{X}_{11}$ Total county population

1939-U. S. Bureau of the Census, Sixteenth Census of the United States: 1940, Population (Washington: Govt. Print. Off., 1943), vol. II (Characteristies of the Population), part 1 (United States Summary and Alabama-District of Columbia). (Table 21.)

1949-U. S. Bureau of the Census, Seventeenth Decennial Census of the United States: 1950, Population (Washington: Govt. Print. Off., 1952), vol. II (Characteristics of the Population), part 5 (California). (Table 21.)

1954-County population estimates for 1955 are not available. Data for 1950 (all above) were used for 1954 . 


\section{APPENDIX B}

TABLE A-1

PRICE INDEXES USED IN ADJUSTING 1939 AND 1949 CURRENT DOLLAR INPUT VALUES TO 1954 CONSTANT DOLLAR VALUES

\begin{tabular}{|c|c|c|c|}
\hline \multirow{2}{*}{ Input item converted to constant dollar value } & \multicolumn{3}{|c|}{ Price indexes } \\
\hline & 1939 & 1949 & 1954 \\
\hline Value of all farm products sold* ...... & 41.1 & 97.0 & 100 \\
\hline Value of all specified crops harvested*. & 38.6 & 90.1 & 100 \\
\hline Value of implements and machinery $\dagger \ldots \ldots \ldots \ldots$ & 49.5 & 86.3 & 100 \\
\hline Value of specified classes of livestock on farmst......... & 47.1 & 116.6 & 100 \\
\hline \multicolumn{4}{|l|}{ Output increasing operating expenses: $\dagger$} \\
\hline 1. Fertilizer and lime................ & 65.2 & 96.8 & 100 \\
\hline 2. Feed & 41.2 & 91.2 & 100 \\
\hline Equipment operating expensest ${ }^{\prime} \ldots \ldots \ldots \ldots \ldots \ldots \ldots \ldots \ldots$ & 63.0 & 90.1 & 100 \\
\hline
\end{tabular}

\section{Source:}

Lee, Ivan M., Annual Index Numbers of Prices Received, Marketing, and Production. All Farm Commodities, and Index Numbers of Acreage of Crops, California, 1910-55 (Berkeley: University of California, Division of Agricultural Sciences, Agricultural Experiment Station, January, 1958), Table 1, col. 1. Giannini Foundation Mimeographed Report No. 201).

$\dagger$ U. S. Department of Agriculture, Agricultural Statistics, 1957 (Washington: Govt. Print. Off., 1958), Table 681 , farm machinery column. 


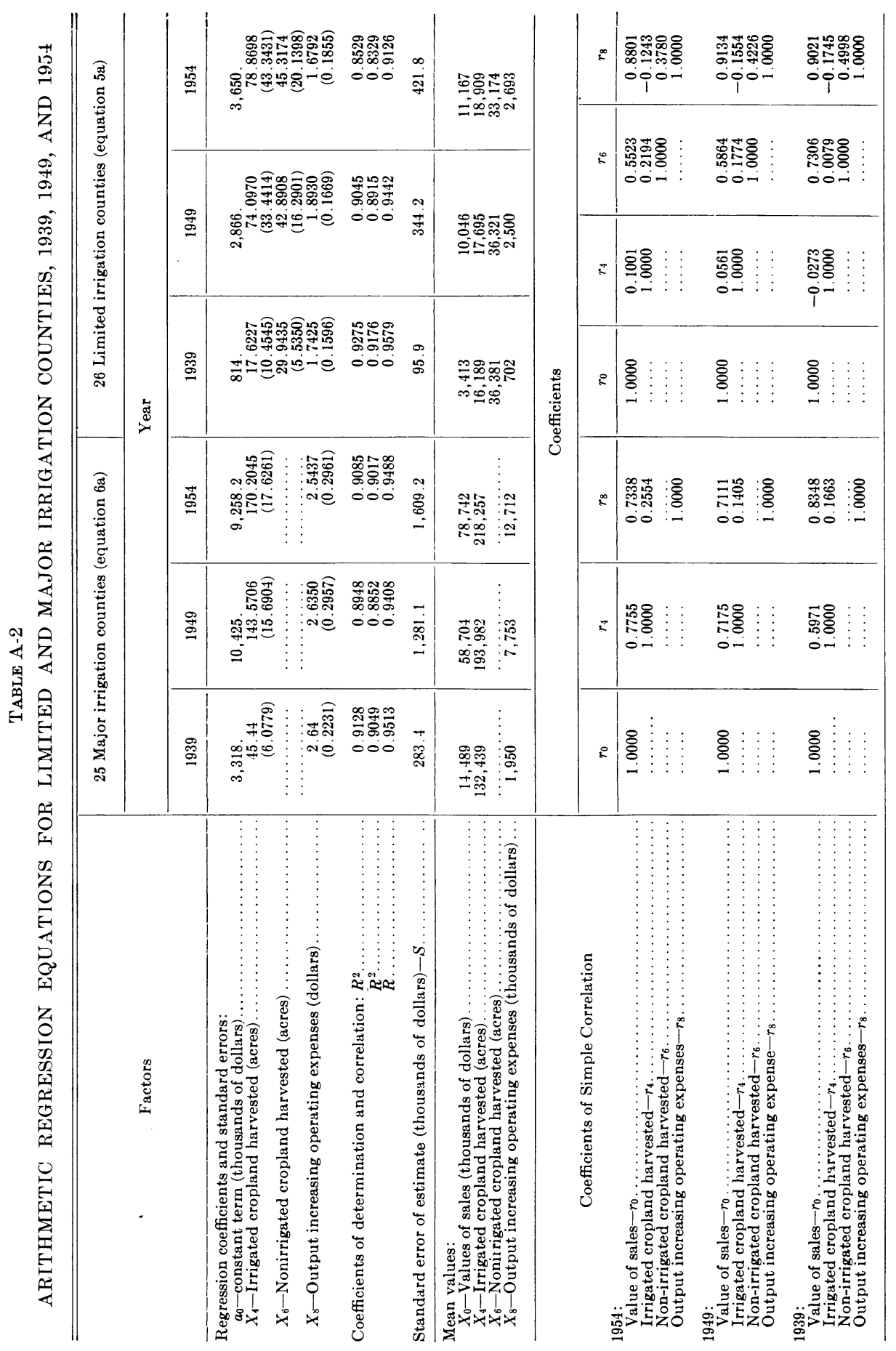


TABLE A-3

CONSTANT DOLLAR REGRESSION EQUATIONS, 1939 AND 1949*

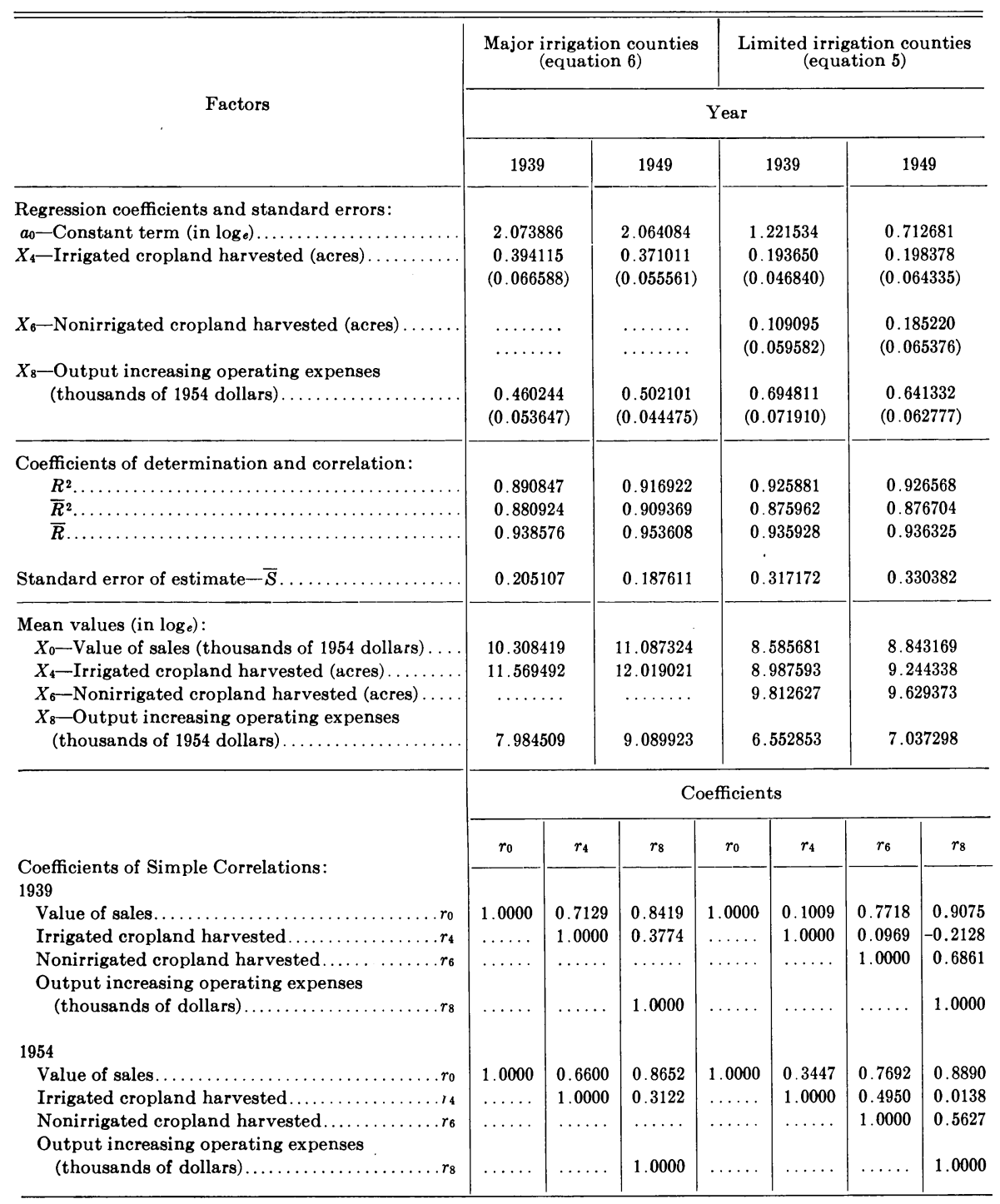

* Actual dollar values for $X_{0}$ and $X_{8}$ for 1939 were converted to 1954 values before computing regression equations. See appendix table A-1 for the price index used. 
TABLE A-4

PROJECTED OUTPUT REQUIREMENTS FOR UNITED STATES AGRICULTURE, 1960 AND 1980

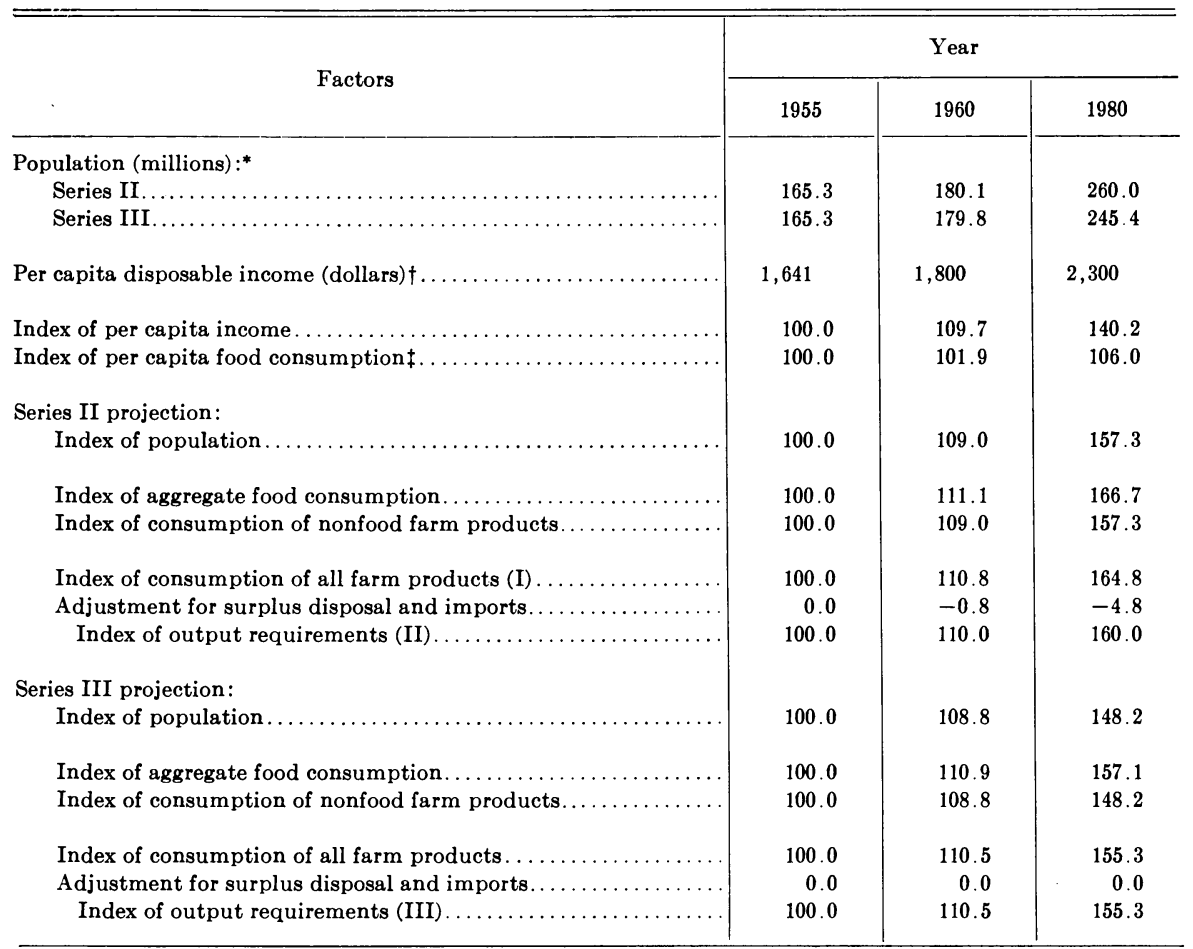

* Zitter, Meyer, and Jacob S. Siegel "Illustrative Projections of the Population of the United States by Age and Sex: 1960 to 1980," Current Population Reports (Washington: Govt. Print. Off., November 10, 1958), Table 1, p. 16. (U. S. Bureau of the Census Population Estimates, Series P-25, No. 187).

$\dagger$ Per-capita disposable personal income was obtained by dividing the total personal disposable income estimates for 1955 from Graham, Robert E., Jr., "Regional Income Distribution in 1957," Survey of Current Business, August, 1958, Table III, p. 12, by the census estimate of population in 1955. The per-capita income estimates for 1960 and 1975 are based on an extension of the same rate of growth as employed by Daly, Rex. F., and Glen T. Barton in "Prospects for Agriculture in a Growing Economy" Paper, AMS presented at Conference on Problems and Policies of American Agriculture, Ames, Iowa, Oct. 27-31, 1958. This is a somewhat higher rate than employed by Collins, N. R., and G. L. Mahren, "Demand Functions and Prospects," in Agricultural Adjustment Problems in a Growing Economy, edited by Earl O. Heady, Howard G. Diesslin, Harold R. Jensen, and Glenn

L. Johnson (Ames: Iowa State College Press, 1958), p. 70.

$\ddagger$ An income elasticity of demand of 0.20 for 1960 and 0.15 for 1980 is assumed. 


\section{APPENDIX C}

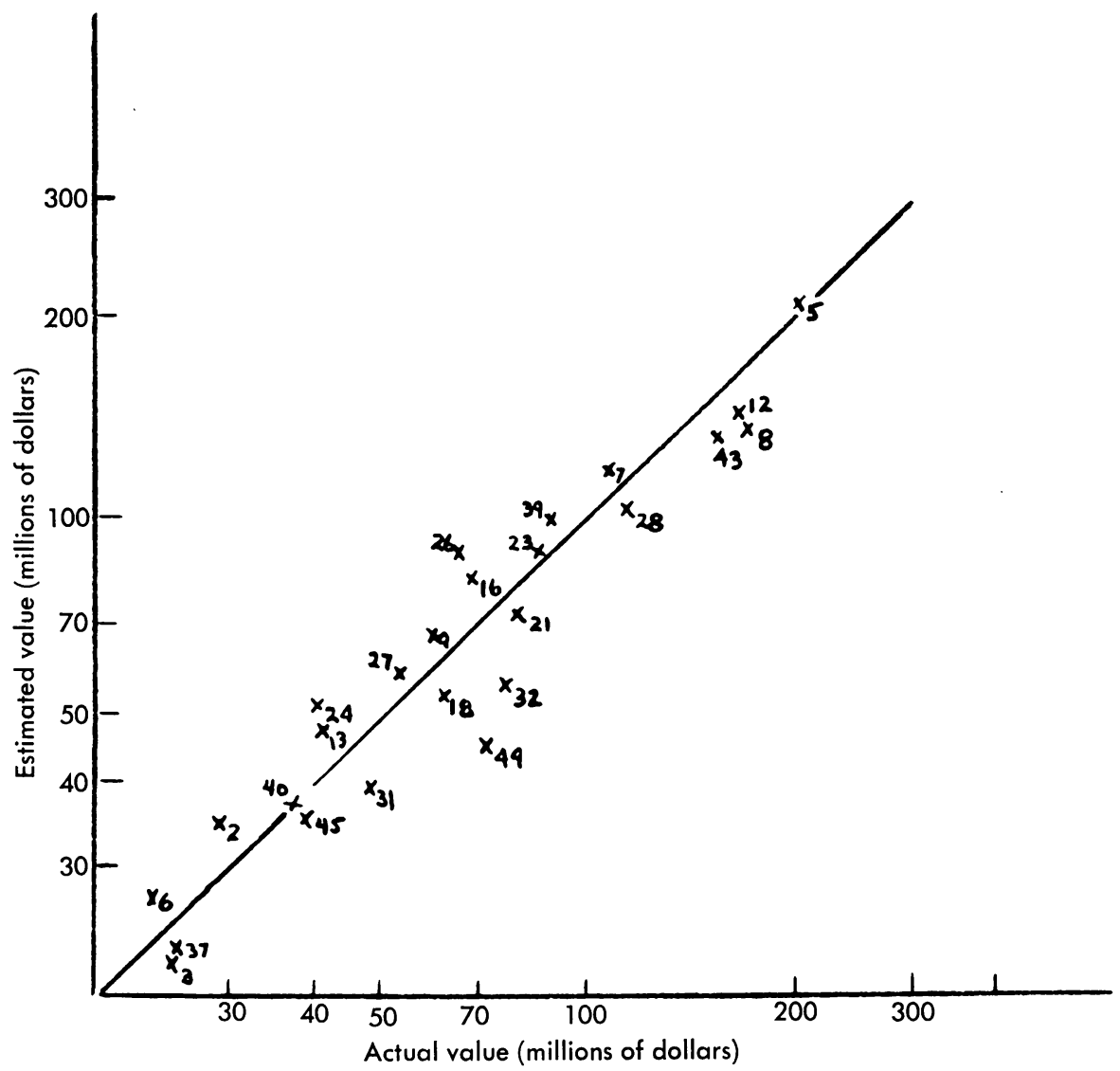

Fig. A-1. Comparison of estimated and actual farm output values; major irrigation counties, 1954 (Equation 6). 


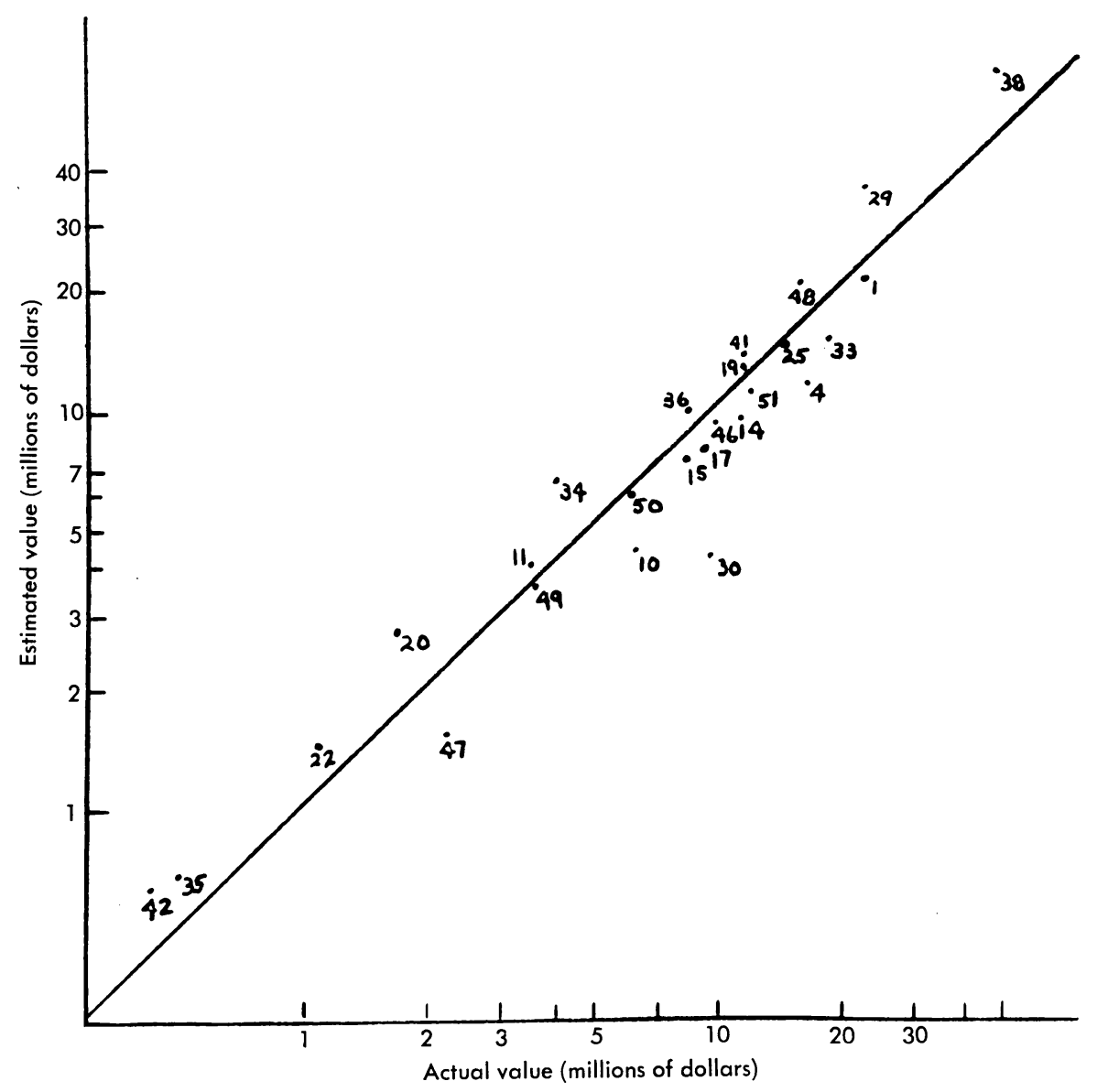

Fig. A-2. Comparison of estimated and actual farm output values; limited irrigation counties, 1954 (Equation 5).

\section{ACKNOWLEDGMENTS}

This report is based on research conducted under California Agricultural Experiment Station Project 1841 which was financed by the University of California Water Resources Center.

The report has benefited from discussion and criticism by Chris Beringer, Michael Brewer, J. C. Headly, Ivan Lee, J. W. Milliman, Stephen Smith, and S. V. Wantrup of the Department of Agricultural Economics, University of California. Discussions and comments by J. W. Thursby and Phil Warren of the California Department of Water Resources were particularly helpful during the project formulation phase of the study. 

The journal Hilgardia is published at irregular intervals, in volumes of about 600 pages. The number of issues per volume varies.

Subscriptions are not sold. The periodical is sent as published only to libraries, or to institutions in foreign countries having publications to offer in exchange.

You may obtain a single copy of any issue free, as long as the supply lasts; please request by volume and issue number from:
Agricultural Publications
207 University Hall
2200 University Avenue
Berkeley 4, California

The limit to nonresidents of California is 10 separate issues on a single order. A list of the issues still available will be sent on request. 


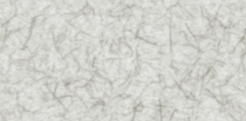

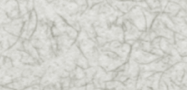

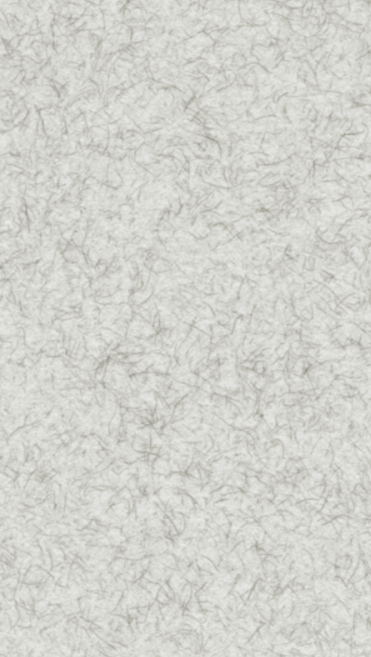

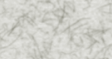

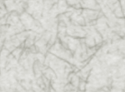

(n)

axtes
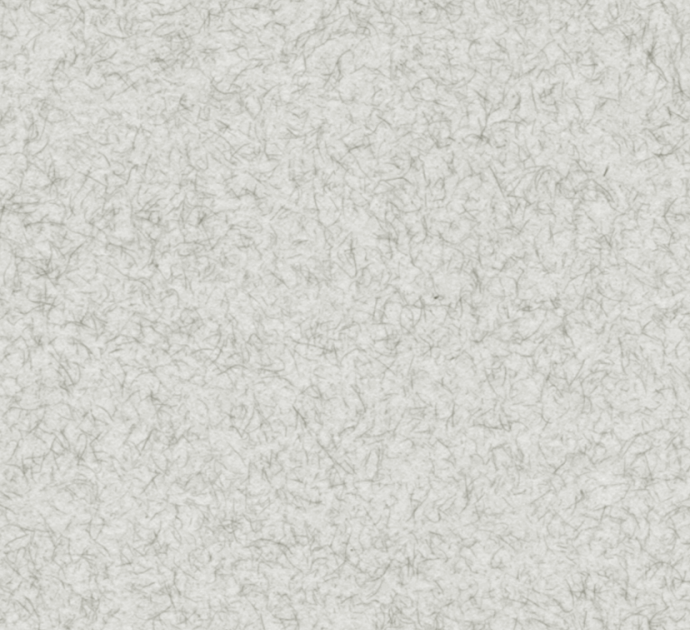

(2)

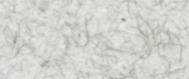

(10.)

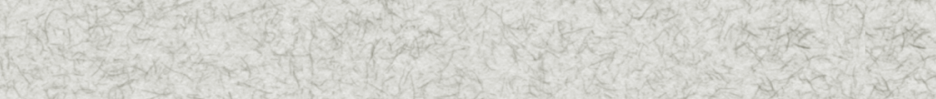

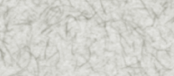

